Publication List

Juntendo Medical Journal

2019. 65 (4), 391-416

\title{
Publications from Juntendo University Graduate School of Medicine, 2017 [2/6]
}

\section{Department of Neurology}

$\langle$ Original Articles〉

1) Hattori N, Hasegawa K, Sato K, Mitsuyama E, Numachi Y: Clinical evaluation of ropinirole controlled-release formulation at $18-24 \mathrm{mg} /$ day in Japanese patients with Parkinson's disease. Parkinsonism Relat Disord, 2017; 40: 33-39.

2) Ando M, Fiesel FC, Hudec R, Caulfield TR, Ogaki K, Górka-Skoczylas P, Koziorowski D, Friedman A, Chen L, Dawson VL, Dawson TM, Bu G, Ross OA, Wszolek ZK, Springer W: The PINK1 p.I368N mutation affects protein stability and ubiquitin kinase activity. Mol Neurodegener, 2017; 24: 32.

3) Cossu D, Yokoyama K, Tomizawa Y, Momotani E, Hattori N: Altered humoral immunity to mycobacterial antigens in Japanese patients affected by inflammatory demyelinating diseases of the central nervous system. Sci Rep, 2017; 7: 3179.

4) Daida K, Nishioka K, Li Y, Nakajima S, Tanaka R, Hattori N: CSF1R Mutation p.G589R and the Distribution Pattern of Brain Calcification. Intern Med, 2017; 56: 25072512.

5) Fujimori K, Matsumoto T, Kisa F, Hattori N, Okano H, Akamatsu W: Escape from Pluripotency via Inhibition of TGF- $\beta / \mathrm{BMP}$ and Activation of Wnt Signaling Accelerates Differentiation and Aging in hPSC Progeny Cells. Stem Cell Reports, 2017; 9: 1675-1691.

6) Fukae J, Fujioka S, Yanamoto S, Mori A, Nomi T, Hatano T, Fukuhara K, Ouma S, Hattori N, Tsuboi Y: Serum uric acid level is linked to the disease progression rate in male patients with multiple system atrophy. Clin Neurol Neurosurg, 2017; 158: 15-19.

An asterisk $(*)$ denotes doctoral works by Japanese students A dugger $(\dagger)$ denotes doctoral works by non-Japanese students.
7) Fukuda R, Miyamoto N, Hayashida A, Ueno Y, Yamashiro K, Tanaka R, Hattori N: Acute Hearing Loss Caused by Decreasing Anterior Inferior Cerebellar Arterial Perfusion in a Patient with Vertebral Artery Stenosis. J Stroke Cerebrovasc Dis, 2017; 26: e119-e121.

8) Fukuhara T, Kim J, Hokaiwado S, Nawa M, Okamoto H, Kogiso T, Watabe T, Hattori N: A novel immunotoxin reveals a new role for CD321 in endothelial cells. PLoS One, 2017; 12: e0181502.

9) Goto M, Kamagata K, Hatano T, Hattori N, Abe O, Aoki S, Hori M, Gomi T: Depressive symptoms in Parkinson's disease are related to decreased left hippocampal volume: correlation with the 15-item shortened version of the Geriatric Depression Scale. Acta Radiol, Epub 2017 Jul 10.

10) Hagiwara A, Hori M, Yokoyama K, Nakazawa M, Ueda R, Horita M, Andica C, Abe O, Aoki S: Analysis of White Matter Damage in Patients with Multiple Sclerosis via a Novel In Vivo MR Method for Measuring Myelin, Axons, and G-Ratio, AJNR Am J Neuroradiol, 2017; 38: 1934-1940.

11) Hagiwara A, Hori M, Yokoyama K, Takemura MY, Andica C, Kumamaru KK, Nakazawa M, Takano N, Kawasaki H, Sato S, Hamasaki N, Kunimatsu A, Aoki S: Utility of a Multiparametric Quantitative MRI Model That Assesses Myelin and Edema for Evaluating Plaques, Periplaque White Matter, and NormalAppearing White Matter in Patients with Multiple Sclerosis: A Feasibility Study. AJNR Am J Neuroradiol, 2017; 38: 237-242.

12) Hagiwara A, Hori M, Yokoyama K, Takemura MY, Andica C, Tabata T, Kamagata K, Suzuki M, Kumamaru KK, Nakazawa M, Takano N, Kawasaki H, Hamasaki N, Kunimatsu A, Aoki

This is a reprint of content originally published in Juntendo University HP. 
S: Synthetic MRI in the Detection of Multiple Sclerosis Plaques. AJNR Am J Neuroradiol, 2017; 38: 257-263.

13) Hara $Y$, Motoi $Y$, Hikishima $K$, Mizuma $H$, Onoe H, Matsumoto S, Elahi M, Okano H, Aoki S, Hattori N: Involvement of the SeptoHippocampal Cholinergic Pathway in Association with Septal Acetylcholinesterase Upregulation in a Mouse Model of Tauopathy. Curr Alzheimer Res, 2017; 14: 94-103.

14) Hatano T, Daida K, Hoshino Y, Li Y, Saitsu H, Matsumoto N, Hattori N: Dystonia due to bilateral caudate hemorrhage associated with a COL4A1 mutation. Parkinsonism Relat Disord, 2017; 40: 80-82.

15) Hatano T, Okuzumi A, Kamagata K, Daida K, Taniguchi D, Hori M, Yoshino H, Aoki S, Hattori N: Neuromelanin MRI is useful for monitoring motor complications in Parkinson's and PARK2 disease. J Neural Transm (Vienna), 2017; 124: 407-415.

* 16) Hosaka Y, Inoshita T, Shiba-Fukushima K, Cui C, Arano T, Imai Y, Hattori N: Reduced TDP-43 Expression Improves Neuronal Activities in a Drosophila Model of Perry Syndrome. EBioMedicine, 2017; 21: 218-227.

17) Ikeda A, Matsushima T, Daida K, Nakajima S, Conedera S, Li Y, Yoshino H, Oyama G, Funayama M, Nishioka K, Hattori N: A novel mutation of $\mathrm{CHCHD} 2 \mathrm{p}$. R8H in a sporadic case of Parkinson's disease. Parkinsonism Relat Disord, 2017; 34: 66-68.

18) Inoshita $T$, Arano $T$, Hosaka $Y$, Meng $H$, Umezaki Y, Kosugi S, Morimoto T, Koike M, Chang HY, Imai Y, Hattori N: Vps35 in cooperation with LRRK2 regulates synaptic vesicle endocytosis through the endosomal pathway in Drosophila. Hum Mol Genet, 2017; 26: 2933-2948.

19) Iwamuro $H$, Tachibana $Y$, Ugawa $Y$, Saito $N$, Nambu A: Information processing from the motor cortices to the subthalamic nucleus and globus pallidus and their somatotopic organizations revealed electrophysiologically in monkeys. Eur J Neurosci, 2017; 46: 2684-2701.

*20) Jo T, Yoshimi K, Takahashi T, Oyamaa G, Hattori N: Dual use of rectangular and triangular waveforms in voltammetry using a carbon fiber microelectrode to differentiate norepinephrine from dopamine. J Electroanal Chem (Lausanne), 2017; 802: 1-7.

21) Jurjević I, Miyajima M, Ogino I, Akiba C, Nakajima M, Kondo A, Kikkawa M, Kanai M, Hattori N, Arai H: Decreased Expression of hsa-miR-4274 in Cerebrospinal Fluid of Normal Pressure Hydrocephalus Mimics with Parkinsonian Syndromes. J Alzheimers Dis, 2017; 56: 317-325.

22) Kamagata K, Zalesky A, Hatano T, Di Biase MA, Samad OE, Saiki S, Shimoji K, Kumamaru KK, Kamiya K, Hori M, Hattori N, Aoki S, Pantelis C: Connectome Analysis with Diffusion MRI in Idiopathic Parkinson's Disease: Evaluation Using Multi-shell, Multitissue, Constrained Spherical Deconvolution. Neuroimage Clin, 2017; 17: 518-529.

23) Kamagata K, Zalesky A, Hatano T, Ueda R, Di Biase MA, Okuzumi A, Shimoji K, Hori M, Caeyenberghs K, Pantelis C, Hattori N, Aoki S: Gray Matter Abnormalities in Idiopathic Parkinson's Disease: Evaluation by Diffusional Kurtosis Imaging and Neurite Orientation Dispersion and Density Imaging. Hum Brain Mapp, 2017; 38: 3704-3722.

24) Kamakura CK, Ueno Y, Sakai Y, Yoshida H, Aiba S, Hayashi A, Shimura H, Takeda K, Kamakura K, Hattori N, Urabe T: White matter lesions and cognitive impairment may be related to recovery from unilateral spatial neglect after stroke. J Neurol Sci, 2017; 379: 241-246.

25) Kanai T, Uzawa A, Sato Y, Suzuki S, Kawaguchi N, Himuro K, Oda F, Ozawa Y, Nakahara J, Suzuki N, Takahashi YK, Ishibashi S, Yokota T, Ogawa T, Yokoyama K, Hattori N, Izaki S, Oji S, Nomura K, Kaneko J, Nishiyama K, Yoshino I, Kuwabara S: A clinical predictive score for postoperative myasthenic crisis. Ann Neurol, 2017; 82: 841849.

26) Kitamura N, Seyama K, Inoue $Y$, Nagai K, Suzuki M, Moriyama H, Takada T, Tazawa R, Hirai T, Mishima M, Hayashida M, Hirose M, Arai T, Sugimoto C, Hattori N, Watanabe K, Tamada T, Akazawa K, Tanaka T, Nakata K: Risk factors for stomatitis in patients with lymphangioleiomyomatosis during treatment 
with sirolimus: A multicenter investigatorinitiated prospective study. Pharmacoepidemiol Drug Saf, 2017; 26: 1182-1189.

27) Kobayashi M, Nishioka K, Takanashi M, Hattori A, Shojima Y, Hayashida A, Sumii A, Ota T, Terao Y, Yokoyama K, Hattori N: AntiNMDA receptor encephalitis due to largecell neuroendocrine carcinoma of the uterus. J Neurol Sci, 2017; 383: 72-74.

28) Maeda T, Shimo Y, Chiu SW, Yamaguchi T, Kashihara K, Tsuboi Y, Nomoto M, Hattori N, Watanabe H, Saiki H; J-FIRST group: Clinical manifestations of nonmotor symptoms in 1021 Japanese Parkinson's disease patients from 35 medical centers. Parkinsonism Relat Disord, 2017; 38: 54-60.

29) Matsuki Y, Miyazaki S, Yoshida K, Ogura A, Sasazawa Y, Takao K, Simizu S: Synthesis and evaluation of biological activities of vibsanin A analogs. Bioorg Med Chem Lett, 2017; 27: 4536-4539.

30) Matsushima T, Conedera S, Tanaka R, Li Y, Yoshino H, Funayama M, Ikeda A, Hosaka Y, Okuzumi A, Shimada Y, Yamashiro K, Motoi Y, Nishioka K, Hattori N: Genotype-phenotype correlations of cysteine replacement in CADASIL. Neurobiol Aging, 2017; 50: 169. e7-169.e14.

31) Meng H, Yamashita C, Shiba-Fukushima K, Inoshita T, Funayama M, Sato S, Hatta T, Natsume T, Umitsu M, Takagi J, Imai Y, Hattori N: Loss of Parkinson's diseaseassociated protein CHCHD2 affects mitochondrial crista structure and destabilizes cytochrome c. Nat Commun, 2017; 8: 15500.

32) Miki Y, Yoshizawa T, Morohashi S, Seino Y, Kijima H, Shoji M, Mori A, Yamashita C, Hatano T, Hattori N, Wakabayashi K: Neuropathology of PARK14 is identical to idiopathic Parkinson's disease. Mov Disord, 2017; 32: 799-800.

33) Mishima T, Fujioka S, Tomiyama H, Yabe I, Kurisaki R, Fujii N, Neshige R, Ross OA, Farrer MJ, Dickson DW, Wszolek ZK, Hattori N, Tsuboi Y: Establishing diagnostic criteria for Perry syndrome. J Neurol Neurosurg Psychiatry, Epub 2017 Oct 31.

34) Miyamoto N, Tanaka R, Ueno Y, Watanabe M, Kurita N, Hira K, Shimada Y, Kuroki T,
Yamashiro K, Urabe T, Hattori N: Analysis of the Usefulness of the WORSEN Score for Predicting the Deterioration of Acute Ischemic Stroke. J Stroke Cerebrovasc Dis, 2017; 26: 2834-2839.

35) Miyamoto N, Tanaka R, Ueno Y, Watanabe M, Kurita N, Hira K, Shimada Y, Kuroki T, Yamashiro K, Urabe T, Hattori N: Analysis of the usefulness of the WORSEN score for predicting the deterioration of acute ischemic stroke. J Stroke Cerebrovasc Dis, 2017; 26: 2834-2839.

36) Mizuno Y, Hattori N, Kondo T, Nomoto M, Origasa H, Takahashi R, Yamamoto M, Yanagisawa N: A Randomized Double-Blind Placebo-Controlled Phase III Trial of Selegiline Monotherapy for Early Parkinson Disease. Clin Neuropharmacol, 2017; 40: 201207.

37) Morishita T, Hilliard JD, Okun MS, Neal D, Nestor KA, Peace D, Hozouri AA, Davidson MR, Bova FJ, Sporrer JM, Oyama G, Foote KD: Postoperative lead migration in deep brain stimulation surgery: Incidence, risk factors, and clinical impact. PLoS One, 2017; 12: e 0183711.

38) Naito H, Takahashi T, Kamada M, Morino H, Yoshino H, Hattori N, Maruyama H, Kawakami H, Matsumoto M: First report of a Japanese family with spinocerebellar ataxia type 10: The second report from Asia after a report from China. PLoS One, 2017; 12: e0177955.

*39) Nakajima A, Shimo Y, Uka T, Hattori N: Subthalamic nucleus and globus pallidus interna influence firing of tonically active neurons in the primate striatum through different mechanisms. Eur J Neurosci, 2017; 46: 2662-2673.

40) Nakashima Y, Ohta S, Wolf AM: Blue lightinduced oxidative stress in live skin. Free Radic Biol Med, 2017; 108: 300-310.

* 41) Nakayama S, Suda A, Nakanishi A, Motoi Y, Hattori N: Galantamine Response Associates with Agitation and the Prefrontal Cortex in Patients with Alzheimer's Disease. J Alzheimers Dis, 2017; 57: 267-273.

42) Nishioka K, Fujimaki M, Kanai K, Ishiguro Y, Nakazato T, Tanaka R, Yokoyama K, Hattori 
N: Demyelinating Peripheral Neuropathy Due to Renal Cell Carcinoma. Intern Med, 2017; 56: 101-104.

43) Nishioka K, Kanai K, Hattori N: Paraneoplastic neuromyotonia due to lung carcinoma and invisible muscle cramps evaluated using ultrasonography. J Neurooncol, 2017; 134: 243-244.

44) Nishioka K, Uchida T, Usui C, Tanaka R, Matsushima T, Matsumoto Y, Nakamura I, Nishioka K, Hattori N: High prevalence of anti-TSH receptor antibody in fibromyalgia syndrome. Int J Rheum Dis, 2017; 20: 685690.

45) Okamoto S, Murano T, Suzuki T, Uematsu S, Niwa Y, Sasazawa Y, Dohmae N, Bujo H, Simizu $\mathrm{S}$ : Regulation of secretion and enzymatic activity of lipoprotein lipase by C-mannosylation. Biochem Biophys Res Commun, 2017; 486: 558-563.

46) Ono $T$, Kamimura N, Matsuhashi $T$, Nagai $T$, Nishiyama T, Endo J, Hishiki T, Nakanishi T, Shimizu N, Tanaka H, Ohta S, Suematsu M, Ieda M, Sano M, Fukuda K, Kaneda R: The histone 3 lysine 9 methyltransferase inhibitor chaetocin improves prognosis in a rat model of high salt diet-induced heart failure. Sci Rep, 2017; 7: 39752.

47) Ouma S, Fukae J, Fujioka S, Yamamoto S, Hatano T, Yoritaka A, Okuma Y, Kashihara KI, Hattori N, Tsuboi Y: The Risk Factors for the Wearing-off Phenomenon in Parkinson's Disease in Japan: A Cross-sectional, Multicenter Study. Intern Med, 2017; 56: 19611966.

48) Puschmann A, Fiesel FC, Caulfield TR, Hudec $\mathrm{R}$, Ando $\mathrm{M}$, Truban $\mathrm{D}$, Hou X, Ogaki K, Heckman MG, James ED, Swanberg M, Jimenez-Ferrer I, Hansson O, Opala G, Siuda J, Boczarska-Jedynak M, Friedman A, Koziorowski D, Rudzinska-Bar M, Aasly JO, Lynch T, Mellick GD, Mohan M, Silburn PA, Sanotsky Y, Vilariño-Güell C, Farrer MJ, Chen L, Dawson VL, Dawson TM, Wszolek ZK, Ross OA, Springer W: Heterozygous PINK1 p.G411S in rapid eye movement sleep behaviour disorder. Brain, 2017; 140: 98-117.

49) Sadatsuki R, Kaneko H, Kinoshita M, Futami I, Nonaka R, Culley KL, Otero M, Hada S,
Goldring MB, Yamada Y, Kaneko K, ArikawaHirasawa E, Ishijima M: Perlecan is required for the chondrogenic differentiation of synovial mesenchymal cells through regulation of Sox9 gene expression. J Orthop Res, 2017; 35: 837-846.

50) Saiki S, Hatano T, Fujimaki M, Ishikawa KI, Mori A, Oji Y, Okuzumi A, Fukuhara T, Koinuma T, Imamichi Y, Nagumo M, Furuya N, Nojiri S, Amo T, Yamashiro K, Hattori N: Decreased long-chain acylcarnitines from insufficient beta-oxidation as potential early diagnostic markers for Parkinson's disease. Sci Rep, 2017; 7: 7328.

51) Sato K, Kerever A, Kamagata K, Tsuruta K, Irie R, Tagawa K, Okazawa H, ArikawaHirasawa E, Nitta N, Aoki I, Aoki S: Understanding microstructure of the brain by comparison of neurite orientation dispersion and density imaging (NODDI) with transparent mouse brain. Acta Radiol Open, 2017; 6: 2058460117703816.

52) Sato S, Li Y, Hattori N: Lysosomal defects in ATP13A2 and GBA associated familial Parkinson's disease. J Neural Transm (Vienna), 2017; 124: 1395-1400.

53) Shiba-Fukushima K, Ishikawa KI, Inoshita T, Izawa $\mathrm{N}$, Takanashi $\mathrm{M}$, Sato $\mathrm{S}$, Onodera $\mathrm{O}$, Akamatsu W, Okano H, Imai Y, Hattori N: Evidence that phosphorylated ubiquitin signaling is involved in the etiology of Parkinson's disease. Hum Mol Genet, 2017; 26: 3172-3185.

54) Shimura H, Tanaka R, Shimada Y, Yamashiro K, Hattori N, Urabe T: Glycyl-alanylhistidine protects $\mathrm{PC} 12$ cells against hydrogen peroxide toxicity. BMC Biochem, 2017; 18: 14 .

55) Straniero L, Guella I, Cilia R, Parkkinen L, Rimoldi V, Young A, Asselta R, Soldà G, Sossi V, Stoessl AJ, Priori A, Nishioka K, Hattori N, Follett J, Rajput A, Blau N, Pezzoli G, Farrer MJ, Goldwurm S, Rajput AH, Duga S: DNAJC12 and dopa-responsive nonprogressive parkinsonism. Ann Neurol, 2017; 82: 640-646.

56) Suzuki K, Okuma Y, Uchiyama T, Miyamoto M, Sakakibara R, Shimo Y, Hattori N, Kuwabara S, Yamamoto T, Kaji Y, Hirano S, 
Kadowaki T, Hirata K; Kanto NMPD investigators: Impact of sleep-related symptoms on clinical motor subtypes and disability in Parkinson's disease: a multicentre crosssectional study. J Neurol Neurosurg Psychiatry, 2017; 88: 953-959.

57) Suzuki K, Okuma Y, Uchiyama T, Miyamoto M, Sakakibara R, Shimo Y, Hattori N, Kuwabara S, Yamamoto T, Kaji Y, Hirano S, Numao A, Hirata K; Kanto NMPD investigators: Characterizing restless legs syndrome and leg motor restlessness in patients with Parkinson's disease: A multicenter casecontrolled study. Parkinsonism Relat Disord, 2017; 44: 18-22.

58) Suzuki K, Okuma Y, Uchiyama T, Miyamoto M, Sakakibara R, Shimo Y, Hattori N, Kuwabara S, Yamamoto T, Kaji Y, Hirano S, Suzuki S, Haruyama Y, Kobashi G, Hirata K; Kanto NMPD investigators: The prevalence, course and clinical correlates of migraine in Parkinson's disease: A multicentre casecontrolled study. Cephalalgia, Epub 2017 Oct 26.

59) Suzuki S, Akamatsu W, Kisa F, Sone T, Ishikawa KI, Kuzumaki N, Katayama H, Miyawaki A, Hattori N, Okano H: Efficient induction of dopaminergic neuron differentiation from induced pluripotent stem cells reveals impaired mitophagy in PARK2 neurons. Biochem Biophys Res Commun, 2017; 483: 88-93.

60) Takemura MY, Hori M, Yokoyama K, Hamasaki N, Suzuki M, Kamagata K, Kamiya K, Suzuki Y, Kyogoku S, Masutani Y, Hattori N, Aoki S: Alterations of the optic pathway between unilateral and bilateral optic nerve damage in multiple sclerosis as revealed by the combined use of advanced diffusion kurtosis imaging and visual evoked potentials. Magn Reson Imaging, 2017; 39: 24-30.

61) Takeshita Y, Shibata N, Kasanuki K, Nagata T, Shinagawa S, Kobayashi N, Ohnuma T, Suzuki A, Kawai E, Takayama T, Nishioka K, Motoi Y, Hattori N, Nakayama K, Yamada H, Arai H: Genetic association between RAGE polymorphisms and Alzheimer's disease and Lewy body dementias in a Japanese cohort: a case-control study. Int J Geriatr Psychiatry,
2017; 32: 1241-1246.

62) Taniguchi D, Oji Y, Ueno Y, Hirayama S, Fukui M, Miyamoto N, Yamashiro K, Tanaka R, Suzuki K, Hattori N: Limb-Shaking Transient Ischemic Attack Induced by Middle Cerebral Artery Dissection after Lung Surgery. J Stroke Cerebrovasc Dis, 2017; 26: e197-e198.

63) Uchihara Y, Kataoka H, Yoshino H, Syobatake R, Hattori N, Ueno S: Parkin mutation may be associated with serious akinesia in a patient with Parkinson's disease. J Neurol Sci, 2017; 379: 119-121.

64) Ueno Y, Tanaka R, Shimada K, Yamashiro K, Miyamoto N, Miyazaki T, Hira K, Kurita N, Sakurai M, Urabe T, Daida H, Hattori N: Age stratification and impact of eicosapentaenoic and docosahexaenoic to arachidonic acid ratios in ischemic stroke patients. J Atheroscler Thromb, Epub 2017 Dec 2.

65) Ueno Y, Tanaka R, Yamashiro K, Miyamoto N, Hira K, Kurita N, Sakurai M, Urabe T, Shimada K, Miyazaki T, Daida H, Hattori N: Age Stratification and Impact of Eicosapentaenoic Acid and Docosahexaenoic Acid to Arachidonic Acid Ratios in Ischemic Stroke Patients. J Atheroscler Thromb, Epub 2017 Dec 2.

66) Wang L, Heckman MG, Aasly JO, Annesi G, Bozi M, Chung SJ, Clarke C, CrosiersD, Eckstein G, Garraux G, Hadjigeorgiou GM, Hattori N, Jeon B, Kim YJ, Kubo M, Lesage S, Lin JJ, Lynch T, Lichtner P, Mellick GD, Mok V, Morrison KE, Quattrone A, Satake W, Silburn PA, Stefanis L, Stockton JD, Tan EK, Toda T, Brice A, Van Broeckhoven C, Uitti RJ, Wirdefeldt K, Wszolek Z, Xiromerisiou G, Maraganore DM, Gasser T, Krüger R, Farrer MJ, Ross OA, Sharma M; GEOPD Consortium: Evaluation of the interaction between LRRK2 and PARK16 loci in determining risk of Parkinson's disease: analysis of a large multicenter study. Neurobiol Aging, 2017; 49: 217.e1-217.e4.

67) Yamada T, Kerever A, Yoshimura Y, Suzuki Y, Nonaka R, Higashi K, Toida T, Mercier F, Arikawa-Hirasawa E: Heparan sulfate alterations in extracellular matrix structures and fibroblast growth factor-2 signaling 
impairment in the aged neurogenic niche. J Neurochem, 2017; 142: 534-544.

68) Yamamoto H, Arimura S, Nakanishi A, Shimo Y, Motoi Y, Ishiguro K, Murakami K, Hattori $\mathrm{N}$, Aoki S: Age-related effects and gender differences in Japanese healthy controls for [(123)I] FP-CIT SPECT. Ann Nucl Med, 2017; 31: 407-412.

69) Yamashiro K, Tanaka R, Urabe $T$, Ueno $Y$, Yamashiro Y, Nomoto K, Takahashi T, Tsuji $\mathrm{H}$, Asahara T, Hattori N: Gut dysbiosis is associated with metabolism and systemic inflammation in patients with ischemic stroke. PLoS One, 2017; 12: e0171521.

70) Yamashita C, Funayama M, Li Y, Yoshino H, Yamada H, Seino Y, Tomiyama H, Hattori N: Mutation screening of PLA2G6 in Japanese patients with early onset dystonia-parkinsonism. J Neural Transm (Vienna), 2017; 124: 431-435.

71) Yokoyama K, Cossu D, Hattori N: Mycobacterium avium subsp. paratuberculosis in Japanese multiple sclerosis. Clin Exp Neuroimmuno, 2017; 8: 5-6.

72) Yoritaka A, Abe T, Ohtsuka C, Maeda T, Hirayama M, Watanabe H, Saiki H, Oyama G, Fukae J, Shimo Y, Hatano T, Kawajiri S, Okuma Y, Machida Y, Miwa H, Suzuki C, Kazama A, Tomiyama M, Kihara T, Hirasawa M, Shimura H, Hattori N: Erratum to: A randomized double-blind multi-center trial of hydrogen water for Parkinson's disease: protocol and baseline characteristics. BMC Neurol, 2017; 17: 35.

73) Yoritaka A, Hattori N: Differences between responders and non-responders in Parkinson's disease, Advance in Parkinson's disease. Advances in Parkinson's Disease, 2017; 6 .

74) Yoshino H, Hirano M, Stoessl AJ, Imamichi Y, Ikeda A, Li Y, Funayama M, Yamada I, Nakamura Y, Sossi V, Farrer MJ, Nishioka K, Hattori N: Homozygous alpha-synuclein p.A53V in familial Parkinson's disease. Neurobiol Aging, 2017; 57: 248.e7-248.e12.

$\langle$ Reviews〉

1) Hattori $N$, Arano T, Hatano T, Mori A, Imai $Y$ : Mitochondrial-Associated Membranes in Parkinson's Disease. Adv Exp Med Biol, 2017;
997: 157-169.

2) Hattori N, Mizuno Y: Twenty years since the discovery of the parkin gene. J Neural Transm (Vienna), 2017; 124: 1037-1054.

3) Cossu D, Yokoyama K, Hattori N: Conflicting Role of Mycobacterium Species in Multiple Sclerosis. Front Neurol, 2017; 8: 216.

4) Fujimaki M, Saiki S, Sasazawa Y, Ishikawa KI, Imamichi Y, Sumiyoshi K, Hattori N: Immunocytochemical Monitoring of PINK1/ Parkin-Mediated Mitophagy in Cultured Cells. Mitophagy, Epub 2017 Mar 31.

5) Inoshita T, Cui C, Hattori N, Imai Y: Regulation of membrane dynamics by Parkinson's disease-associated genes, J Genet, Epub 2017 Nov 23.

6) Inoshita T, Hattori N, Imai Y: Live Imaging of Axonal Transport in the Motor. Bio Protoc, 2017; 7: e2631.

7) Kasemsuk C, Oyama G, Hattori N: Management of impulse control disorders with deep brain stimulation: A double-edged sword. J Neurol Sci, 2017; 374: 63-68.

8) Meng H, Yamashita C, Hattori N, Imai Y: Measurements of the mitochondrial respiration and glycolytic activity in Drosophila embryonic cells. Protocol Exchange, Epub 2017 Jul 10.

9) Silva de Lima AL Silva de Lima AL, Evers LJ, Hahn T, Bataille L, Hamilton JL, Little MA, Okuma Y, Bloem BR, Faber MJ: Freezing of gait and fall detection in Parkinson's disease using wearable sensors: a systematic review. J Neurol, 2017; 264: 1642-1654.

10) Yokoyama K, Hattori N: Management of myasthenia gravis in daily practice for general neurologists and healthcare professionals. Clin Exp Neuroimmuno, 2017; 8: 162-170.

〈Books〉

1) Inoshita $T$, Shiba-Fukushima $K$, Meng $H$, Hattori N, Imai Y: Monitoring Mitochondrial Changes by Alteration of the PINK1-Parkin Signaling in Drosophila. Methods Mol Biol, Epub 2017 Mar 22.

\section{Department of Neurosurgery}

$\langle$ Original Articles〉

* 1) Akiba C, Nakajima M, Miyajima M, Ogino I, 
Miura M, Inoue R, Nakamura E, Kanai F, Tada N, Kunichika M, Yoshida M, Nishimura K, Kondo A, Sugano H, Arai H: Leucine-rich alpha 2-glycoprotein overexpression in the brain contributes to memory impairment. Neurobiol Aging, 2017; 60: 11-19.

2) Akiyama O, Güngör A, Middlebrooks EH, Kondo A, Arai H: Microsurgical anatomy of the maxillary artery for extracranial-intracranial bypass in the pterygopalatine segment of the maxillary artery. Clin Anat, Epub 2017 Nov 29.

3) Akiyama O, Matsushima K, Nunez M, Matsuo S, Kondo A, Arai H, Rhoton AL Jr, Matsushima T: Microsurgical anatomy and approaches around the lateral recess with special reference to entry into the pons. J Neurosurg, 2017; 17: 1-12.

* 4) Akiyama O, Matsushima K, Gungor A, Matsuo S, Goodrich DJ, Tubbs RS, Klimo P Jr, Cohen-Gadol AA, Arai H, Rhoton AL Jr: Microsurgical and endoscopic approaches to the pulvinar. J Neurosurg, 2017; 127: 630645.

5) Fujii $T$, Otani N, Takeuchi S, Toyooka $T$, Wada K, Mori K: Horizontal distance of anterior communicating artery aneurysm neck from anterior clinoid process is critically important to predict postoperative complication in clipping via pterional approach. Surg Neurol Int, 2017; 8: 200.

6) Hayakawa M, Matsumaru Y, Sakai N, Yamagami H, Ihara K, Ogasawara K, Oishi H, Ito Y, Sugiu K, Yoshimura S: Periprocedural Evaluation and Management against Cerebral Hyperperfusion Syndrome after Carotid Artery Stenting in Japan: A Nationwide Questionnaire Survey. Journal of Neuroendovascular Therapy, 2017; 11: 341-350.

7) Iimura $\mathrm{Y}$, Jones K, Hattori K, Okazawa Y, Noda A, Hoashi K, Nonoda Y, Asano E, Akiyama T, Go C, Ochi A, Snead OC 3rd, Donner EJ, Rutka JT, Drake JM, Otsubo H: Epileptogenic high-frequency oscillations skip the motor area in children with multilobar drug-resistant epilepsy. Clin Neurophysiol, 2017; 128: 1197-1205.

8) Irie $R$, Tsuruta $K$, Hori $M$, Suzuki $M$, Kamagata K, Nakanishi A, Kamiya K, Naka- jima M, Miyajima M, Arai H, Aoki S: Neurite orientation dispelson and density imaging for evaluateon of corticespinal tract in idiopathic normal pressure hydrocephalus. Jpn J Radiol, 2017; 35: 25-30.

9) Ishi A, Oishi H: Pipeline-Indications, Patient Selection and Avoidance of Complications. Journal of Neuroendovascular Therapy, 2017; 11: $138-146$.

10) Ishikawa K, Omori K, Takeuchi I, Jitsuiki K, Yoshizawa T, Ohsaka H, Nakao Y, Yamamoto T, Yanagawa Y: A comparison between evacuation from the scene and interhospital transportation using a helicopter for subarachnoid hemorrhage. Am J Emerg Med, 2017; 35: 543-547.

11) Izumi $K$, Tsutsumi $S$, Hara T, Ishii H, Ito $M$, Yasumoto Y: Large presacral epidermoid cyst in an asymptomatic woman. Radiol Case Rep, 2017; 12: 738-740.

12) Jurjević I, Miyajima M, Ogino I, Akiba C, Nakajima M, Kondo A, Kikkawa M, Kanai M, Hattori N, Arai H: Decreased Expression of hsa-miR-4274 in Cerebrospinal Fluid of Normal Pressure Hydrocephalus Mimics with Parkinsonian Syndromes. J Alzheimers Dis, 2017; 56: 317-325.

13) Kameda M, Yamada S, Atsuchi M, Kimura T, Kazui H, Miyajima M, Mori E, Ishikawa M, Date I: SINPHONI and SINPHONI-2 Investigators. Cost-effectiveness analysis of shunt surgery for idiopathic normal pressure hydrocephalus based on the SINPHONI and SINPHONI-2 trials. Acta Neurochir (Wien), 2017; 159: 995-1003.

14) Kamiya K, Hori $M$, Irie $R$, Miyajima $M$, Nakajima M, Kamagata K, Tsuruta K, Saito A, Nakazawa M, Suzuki Y, Mori H, Kunimatsu A, Arai H, Aoki S, Abe O: Diffusion imaging of reversible and irreversible microstructural changes within the corticospinal tract in idiopathic normal pressure hydrocephalus. Neuroimage Clin, 2017; 14: 663-671.

15) Kodama T, Tsutsumi S, Abe E, Nonaka S, Suzuki T, Ishii $\mathrm{H}$, Ito $\mathrm{M}$, Yasumoto Y: Supratentorial acute subdural hematoma presenting immediately after evacuation of spontaneous cerebellar hemorrhage. Neurosurg Emerg, 2017; 22: 70-73. 
16) Kumagai K, Takeuchi S, Otani N, Komiyama M, Mori K: Agenesis of the Internal Carotid Artery with Transcavernous Anastomosis Associated with Anterior Communicating Artery Aneurysms. Asian J Neurosurg, 2017; 12: 801-803.

* 17) Kurimoto T, Kondo A, Ogino I, Fujimura J, Arakawa A, Arai H, Shimizu T: Effect of O6-methylguanine-DNA methyltransferase methylation in medulloblastoma. Mol Clin Oncol, 2017; 7: 1107-1111.

18) Kuriyama N, Miyajima M, Nakajima $M$, Kurosawa M, Fukushima W, Watanabe Y, Ozaki E, Hirota Y, Tamakoshi A, Mori E, Kato T, Tokuda T, Urae A, Arai H: Nationwide hospital-based survey of idiopathic normal pressure hydrocephalus in Japan: Epidemiological and clinical characteristics. Brain Behav, 2017; 7: e00635.

19) Lang FM, Hossain A, Gumin J, Momin EN, Shimizu Y, Ledbetter D, Shahar T, Yamashita S, Parker-Kerrigan B, Fueyo J, Sawaya R, Lang FF: Mesenchymal Stem Cells as Natural Bio-Factories for Exosomes Carrying miR-124a in the Treatment of Gliomas. Neuro Oncol, Epub 2017 August 14.

20) Matsuoka H, Ohara Y, Tomita Y, Kikuchi N, Hirano Y, Uchikado H, Mizuno J: Initial radiological fndings utilizing titanium basket for cervical open door laminoplasty. Surg Neurol Int, 2017; 8: 217.

21) Mori K, Wada K, Otani N, Tomiyama A, Toyooka T, Fujii K, Kumagai K, Takeuchi S, Tomura S, Yamamoto T, Nakao Y, Arai H: Validation of effectiveness of keyhole clipping in nonfrail elderly patients with unruptured intracranial aneurysms. J Neurosurg, 2017; 6: 1-8.

22) Mori K, Wada K, Otani N, Tomiyama A, Toyooka T, Fujii K, Kumagai K, Takeuchi S, Tomura S, Yamamoto T, Nakao Y, Arai H: Validation of effectiveness of keyhole clipping in non-frail elderly patients with unruptured intracranial aneurysms. J Neurosurg, 2017; 127: $1307-1314$.

23) Nakajima A, Oyama G, Jo T, Shimo Y, Umemura A, Nakajima M, Ishii $\mathrm{H}$, Arai $\mathrm{H}$, Hattori N: Rescue Pallidal Stimulation for Diphasic and Stimulation induced Dyskinesia after Successful Subthalamic Stimulation for Parkinson's Disease. Neurol Clin Neurosci, 2017; 5: 127-128.

24) Noda K, Hattori N, Okuma Y, Yamamoto T: Chronic subdural haematoma presenting as freezing of gait. BMJ Case Rep, 2017; 2017. pii: bcr-2017-221469.

25) Ohara Y, Shimizu S, Mizuno J: Percutaneous endoscopic lumbar laminectomy. Mini-invasive Surg, 2017; 1: 74-80.

26) Oishi H, Sakai N: Report of flow diverter clinical trials in Japan. Journal of Neuroendovascular Therapy, 2017; 11: 124-132.

27) Orgun D, Horiguchi M, Hayashi A, Shimoji K, Arai H, Mizuno H: Conservative Treatment of Large Aplasia Cutis Congenita of the Scalp with Bone Defect with Basic Fibroblast Growth Factor Application. J Craniofac Surg, 2017; 28: e154-e158.

28) Otani N, Toyooka T, Wada K, Mori K: Modified extradural temporopolar approach with suction decompression for clipping of large paraclinoid aneurysm: Technical note. Surg Neurol Int, 2017; 18: 148.

29) Otani N, Toyooka T, Fujii K, Kumagai K, Takeuchi S, Tomiyama A, Nakao Y, Yamamoto T, Wada K, Mori K: "Birdlime" technique using TachoSil tissue sealing sheet soaked with fibrin glue for sutureless vessel transposition in microvascular decompression: operative technique and nuances. J Neurosurg, 2017; 11: 1-8.

30) Otani N, Toyooka T, Takeuchi S, Tomiyama A, Wada K, Mori K: Modified extradural temporopolar approach with mini-peeling of dura propria for paraclinoid and/or parasellar tumors: Operative technique and nuances. Surg Neurol Int, 2017; 22: 199.

31) Otani N, Wada K, Toyooka T, Takeuchi S, Tomiyama A, Mori K: Usefulness of dural surface tracing of the cortical vessels with indocyanine green videoangiography just prior to dural opening for various cerebrovascular diseases. Surg Neurol Int, 2017; 22: 201.

32) Otani N, Morimoto Y, Fujii K, Toyooka T, Wada K, Mori K: Flexible Ultrathin Endoscope Integrated with Irrigation Suction Apparatus for Assisting Microneurosurgery. World Neurosurg, 2017; 108: 589-594. 
33) Sato Y, Simeon WM, Iimura Y, Ochi A, Sam MD, Otsubo H: Spatiotemporal changes of multiscale entropy in gamma oscillations associated with focal ictogenesis. Sci Rep, 2017; 7: 9362.

34) Sekiguchi K, Tsutsumi S, Arai S, Nonaka S, Suzuki T, Ishii H, Izumi H, Yasumoto Y: Osteochondroma Presenting as a Calcified Mass in the Sellar Region and Review of the Literature. J Neurol Surg A Cent Eur Neurosurg, 2017; 78: 380-385.

35) Sekihara K, Saitoh K, Han L, Ciurea S, Yamamoto S, Kikkawa M, Kazuno S, Taka H, Kaga N, Arai H, Miida T, Andreeff M, Konopleva M, Tabe Y: Targeting mantle cell lymphoma metabolism and survival through simultaneous blockade of mTOR and nuclear transporter exportin-1. Oncotarget, 2017; 8: 34552-34564.

36) Sekimoto S, Oyama G, Jo T, Nakajima A, Shimo Y, Nakajima M, Umemura A, Ito M, Arai H, Hattori N: "Two Odd Targets" Strategy in Deep Brain Stimulation for Parkinson's Disease with Unilateral Levodopa Induced Dystonia. Neurol Clin Neurosci, 2017; 5: 129-130.

37) Seno S, Tomura S, Ono K, Akitomi S, Sekine Y, Yoshimura Y, Tanaka Y, Ikeuchi H, Saitoh D: The Relationship between Functional Outcome and Prehospital Time Interval in Patients with Cerebral Infarction. J Stroke Cerebrovasc Dis Dec, 2017; 26: 2800-2805.

38) Shimoji T, Kimura T, Shimoji K, Miyajima M: The metopic-sagittal craniosynostosisreport of 35 operative cases. Childs Nerv Syst, 2017; 33: 1335-1348.

*39) Suzuki M, Kondo A, Ogino I, Arai H, Tomita T, Sredni ST: Overexpression of TEAD4 in atypical teratoid/rhabdoid tumor: New insight to the pathophysiology of an aggressive brain tumor. Pediatr Blood Cancer, 2017; 64 (7).

40) Tabe Y, Yamamoto S, Saitoh K, Sekihara K, Monma N, Ikeo K, Mogushi K, Shikami M, Ruvolo VR, Ishizawa J, Hail N, Kazuno S, Igarashi M, Matsushita H, Yamanaka Y, Arai H, Nagaoka I, Miida T, Hayashizaki Y, Konopleva M, Andreeff M: Bone Marrow Adipocytes Facilitate Fatty Acid Oxidation
Activating AMPK and a Transcriptional Network Supporting Survival of Acute Monocytic Leukemia Cells. Cancer Res, 2017; 77: 1453-1464.

41) Takahashi Y, Hori M, Shimoji K, Miyajima M, Akiyama O, Arai H, Aoki S: Changes in delta ADC reflect intracranial pressure changes in craniosynostosis. Acta Radiol Open, 2017; 6: 2058460117728535.

42) Takano N, Suzuki M, Irie R, Yamamoto M, Hamasaki N, Kamagata K, Kumamaru KK, Hori M, Oishi H, Aoki S: Usefulness of NonContrast-Enhanced MR Angiography Using a Silent Scan for Follow-Up after Y-Configuration Stent-Assisted Coil Embolization for Basilar Tip Aneurysms. AJNR Am J Neuroradiol, 2017; 38: 577-581.

43) Teramoto S, Yamamoto T, Nakao Y, Watanabe M: Novel Anatomic Classification of Spontaneous Thalamic Hemorrhage Classified by Vascular Territory of Thalamuss. World Neurosurg, 2017; 104: 452-458.

44) Toyooka T, Otani N, Wada K, Tomiyama A, Ueno H, Fujii K, Yamamoto T, Nakao Y, Mori K: Effect of Fibrin Glue Injection Into the Cavernous Sinus for Hemostasis During Transcavernous Surgery on the Cerebral Venous Draining System. Oper Neurosurg (Hagerstown), 2017; 13: 224-231.

45) Toyooka T, Otani N, Wada K, Tomiyama A, Takeuchi S, Fujii K, Kumagai K, Fujii T, Mori K: Head-up display may facilitate safe keyhole surgery for cerebral aneurysm clipping. J Neurosurg, 2017; 1: 1-7.

46) Tsutsumi S, Fernandez-Miranda JC, Ono H, Yasumoto Y: The cisternal segments of the oculomotor nerve: a magnetic resonance imaging study. Surg Radiol Anat, 2017; 39: 323-331.

47) Tsutsumi S, Ishii H, Ono H, Yasumoto Y: The third ventricle roof: An anatomical study using constructive interference in steadystate magnetic resonance imaging. Surg Radiol Anat, 2017; 40: 123-128.

48) Tsutsumi S, Ishii $\mathrm{H}$, Ono $\mathrm{H}$, Yasumoto $\mathrm{Y}$ : Visualization of the cavum septi pellucidi, cavum Vergae, and cavum veli interpositi using magnetic resonance imaging. Surg Radiol Anat, 2017; 40: 159-164. 
49) Tsutsumi S, Ogino H, Miyajima M, Nonaka S, Ito M, Yasumoto Y, Arai H: Role of cathepsin $\mathrm{K}$ in the development of chronic subdural hematoma. J Clin Neurosci, 2017; 45: 343347.

50) Tsutsumi S, Ono H, Yasumoto Y: Immobile cerebral veins in the context of positional brain shift: an undescribed risk factor for acute subdural hemorrhage. Surg Radiol Anat, 2017; 39: 1063-1067.

51) Tsutsumi S, Ono H, Yasumoto Y: Pile driving into the skull and suspending the bridging veins? An undescribed role of arachnoid granulations. Surg Radiol Anat, 2017; 39: 541-545.

52) Tsutsumi S, Ono H, Yasumoto Y: The cisternal segment of the anterior choroidal artery: an anatomical study using magnetic resonance imaging. Childs Nerv Syst, 2017; 33: 2011-2016.

53) Tsutsumi S, Ono H, Yasumoto Y: The mastoid emissary vein: an anatomic study with magnetic resonance imaging. Surg Radiol Anat, 2017; 39: 351-356.

54) Tsutsumi S, Ono H, Yasumoto Y: The suprapineal recess of the third ventricle: an anatomic study with magnetic resonance imaging. Surg Radiol Anat, 2017; 39: 725-730.

55) Tsutsumi S, Ono H, Yasumoto Y: The tuber cinereum as a circumventricular organ: an anatomical study using magnetic resonance imaging. Surg Radiol Anat, 2017; 39: 747-751.

56) Tsutsumi S, Ono H, Yasumoto Y: Vascular Compression of the Anterior Optic Pathway: A Rare Occurrece? Can Assoc Radiol J, 2017; 68: 409-413.

57) Tsutsumi S, Ono H, Yasumoto Y: Visualization of cerebrospinal fluid-filled spaces in the cavernous sinus using magnetic resonance imaging. J Clin Neurosci, 2017; 45: 332-336.

58) Tsutsumi S, Ono H, Yasumoto Y: Visualization of the olfactory nerve using constructive interference in steady state magnetic resonance imaging. Surg Radiol Anat, 2017; 39: 315-321.

59) Wakabayashi $\mathrm{T}$, Iuchi $\mathrm{T}$, Tsuyuguchi $\mathrm{N}$, Nishikawa R, Arakawa Y, Sasayama T, Miyake K, Nariai T, Narita Y, Hashimoto N, Okuda O, Matsuda H, Kubota K, Ito K,
Nakazato Y, Kubomura K: Diagnostic performance and safety of Positron Emission Tomography using $18 \mathrm{~F}$-Fluciclovine in patients with clinically suspected high- or low-grade gliomas: A multicenter Phase IIb trials. Asia Ocean J Nucl Med Biol, 2017; 5: 10-21.

60) Yamada S, Ishikawa M, Miyajima M, Nakajima M, Atsuchi M, Kimura T, Tokuda T, Kazui H, Mori E: Timed up and go test at tap test and shunt surgery in idiopathic normal pressure hydrocephalus. Neurol Clin Prac, 2017; 7: 98-108.

61) Yamada S, Kimura T, Jingami N, Atsuchi M, Hirai O, Tokuda T, Miyajima M, Kazui H, Mori E, Ishikawa M: SINPHONI-2 Investigators. Disability risk or unimproved symptoms following shunt surgery in patients with idiopathic normal-pressure hydrocephalus: post hoc analysis of SINPHONI-2. J Neurosurg, 2017; 126: 2002-2009.

$\langle$ Reviews〉

1) Parker Kerrigan BC, Shimizu Y, Andreeff M, Lang FF: Mesenchymal stromal cells for the delivery of oncolytic viruses in gliomas. Cytotherapy, 2017; 19: 445-457.

〈Books〉

1) Ohara Y, Mizuno J, Nakagawa H, Okazaki T: Expansive open-door laminoplasty for multiplevel cervical canal stenosis. In: Wolfla C, Resnick DK, eds. Neurosurgical Operative Atlas: Spine and Peripheral Nerves. NY; Thieme Publishers, 2017; 104-108.

2) Wada K: High flow extracranial to intracranial bypass procedure. In ACNS surgical manual second edition. Asian Congress of Neurological Surgeons, 2017; 1-15.

\section{Department of Human Pathology}

〈Original Articles〉

1) Hara $K$, Saito T, Hayashi T, Mitani $K$, Takamochi K, Oh S, Suzuki K, Yao T: Inverse correlation between galectin- 4 and TTF- 1 in lung adenocarcinoma. Virchows Arch, 2017; 471: 375-382.

2) Kosaka T, Azami S, Iino M, Aoki Y, Ogura K, Kitabatake T, Kojima K, Matsumoto T: Combined core needle biopsy and fine needle aspiration cytology using returned cell block 
method is effective for diagnosis of cystic lesions of the breast. J Cytol Histol, 2017; 8: 462.

3) Tajima Y, Murakami T, Saito T, Hiromoto T, Akazawa Y, Sasahara N, Mitomi H, Yao T, Watanabe S: Distinct Involvement of the Sonic Hedgehog Signaling Pathway in Gastric Adenocarcinoma of Fundic Gland Type and Conventional Gastric Adenocarcinoma. Digestion, 2017; 96: 81-91.

4) Kojima M, Shimazaki H, Iwaya K, Nakamura T, Kawachi H, Ichikawa K, Sekine S, Ishiguro S, Shimoda T, Kushima R, Yao T, Fujimori T, Hase K, Watanabe T, Sugihara K, Lauwers GY, Ochiai A: Intramucosal colorectal carcinoma with invasion of the lamina propria: a study by the Japanese Society for Cancer of the Colon and Rectum. Hum Pathol, 2017; 66: 230-237.

5) Fukumura Y, Nakanuma Y, Kakuda Y, Takase M, Yao T: Clinicopathological features of intraductal papillary neoplasms of the bile duct: a comparison with intraductal papillary mucinous neoplasm of the pancreas with reference to subtypes. Virchows Arch, 2017; 471: 65-76.

6) Murakami T, Mitomi H, Yao T, Saito T, Shibuya T, Watanabe S: Epigenetic regulation of Wnt/ $\beta$-catenin signal-associated genes in gastric neoplasia of the fundic gland (chief cell-predominant) type. Pathol Int, 2017; 67: 147-155.

7) Tomishima K, Sai JK, Kanazawa R, Miura H, Shimizu R, Sato K, Ishii S, Saito H, Ito T, Fukumura Y, Shiina S, Watanabe S: Impact of MUC1 expression on the progression of intraductal papillary mucinous neoplasm with worrisome geatures during follow-up. Pancreas, 2017; 46: 1127-1132.

〈Books〉

1) Fukumura $Y$, He C, Hara K, Kakuda $Y$ : Intraductal Papillary Neoplasm of the Bile Duct: A Grossly Visible Preinvasive Neoplasm of the Bile Duct. In: Nakanuma Y, ed. Pathology of the Bile Duct. Switzerland; Springer, 2017; 163-175.

2) Fukumura Y, Mamat O, Yanai Y, Takase M, Sai J: Chapter 7. Intraductal Papillary Neoplasms of the Bile Duct: What Is Known and
What Requires Further Clarification. In: Nakanuma Y, ed. Biliary Diseases with Pancreatic Counterparts: A New Disease Concept (Pathology Research and Practices). NY; Nova Science Publishers, 2017; 137-158.

\section{Department of Cellular and Molecular Pharmacol- ogy}

〈Original Articles〉

1) Uehara A, Murayama T, Yasukochi M, Fill M, Horie M, Okamoto T, Matsuura Y, Uehara K, Fujimoto T, Sakurai T, Kurebayashi N: Extensive $\mathrm{Ca} 2+$ leak through $\mathrm{K} 4750 \mathrm{Q}$ cardiac ryanodine receptors caused by cytosolic and luminal $\mathrm{Ca} 2+$ hypersensitivity. J Gen Physiol, 2017; 149: 199-218.

2) Takaya $R$, Nagai J, Piao $W$, Niisato $E$, Nakabayashi T, Yamazaki Y, Nakamura F, Yamashita N, Kolattukudy P, Goshima Y, Ohshima T: CRMP1 and CRMP4 are required for proper orientation of dendrites of cerebral pyramidal neurons in the developing mouse brain. Brain Res, 2017; 1655: 161-167.

3) Kamikubo Y, Takasugi N, Niisato K, Hashimoto Y, Sakurai T: Consecutive Analysis of BACE1 Function on Developing and Developed Neuronal Cells. J Alzheimers Dis, 2017; 56: 641-653.

4) Fujii $Y$, Itoh $H$, Ohno S, Murayama $T$, Kurebayashi N, Aoki H, Blancard M, Nakagawa Y, Yamamoto S, Matsui Y, Ichikawa M, Sonoda K, Ozawa T, Ohkubo K, Watanabe I, Guicheney P, Horie M: A type 2 ryanodine receptor variant associated with reduced $\mathrm{Ca} 2+$ release and short-coupled torsade de pointe ventricular arrhythmia. Heart Rhythm, 2017; 14: 98-107.

5) Eshima H, Tamura Y, Kakehi S, Kurebayashi N, Murayama T, Nakamura K, Kakigi R, Okada T, Sakurai T, Kawamori R, Watada H: Long-term, but not short-term high-fat diet induces fiber composition changes and impaired contractile force in mouse fasttwitch skeletal muscle. Physiol Rep, 2017; 5: e13250.

6) Yamane M, Yamashita N, Hida T, Kamiya Y, Nakamura F, Kolattukudy P, Goshima Y: A functional coupling between CRMP1 and Nav1.7 for retrograde propagation of 
Semaphorin3A signaling. J Cell Sci, 2017; 130: 1393-1403.

7) Tobe BTD, Crain AM, Winquist AM, Calabrese B, Makihara H, Zhao WN, Lalonde J, Nakamura H, Konopaske G, Sidor M, Pernia $\mathrm{CD}$, Yamashita N, Wada M, Inoue Y, Nakamura F, Sheridan SD, Logan RW, Brandel M, Wu D, Hunsberger J, Dorsett L, Duerr C, Basa RCB, McCarthy MJ, Udeshi ND, Mertins P, Carr SA, Rouleau GA, Mastrangelo L, Li J, Gutierrez GJ, Brill LM, Venizelos N, Chen G, Nye JS, Manji H, Price JH, McClung CA, Akiskal HS, Alda M, Chuang DM, Coyle JT, Liu Y, Teng YD, Ohshima T, Mikoshiba K, Sidman RL, Halpain S, Haggarty SJ, Goshima Y, Snyder EY: Probing the lithium-response pathway in hiPSCs implicates the phosphoregulatory set-point for a cytoskeletal modulator in bipolar pathogenesis. Proc Natl Acad Sci U S A, 2017; 114: E4462-E4471.

8) Nonaka, M, Kurebayashi N, Murayama T, Sugihara M, Terawaki K, Shiraishi S, Miyano K, Hosoda H, Kishida S, Kangawa K, Sakurai T, Uezono Y: Therapeutic potential of ghrelin and des-acyl ghrelin against chemotherapyinduced cardiotoxicity. Endocr J, 2017; 64: S35-S39.

9) Hashimoto K, Kodama A, Honda T, Hanashima A, Ujihara Y, Murayama T, Nishimatsu SI, Mohri S: Fam64a is a novel cell cycle promoter of hypoxic fetal cardiomyocytes in mice. Sci Rep, 2017; 7: 4486.

10) Kobayashi $T$, Miyashita $T$, Murayama $T$, Toyoshima YY: Dynactin has two antagonistic regulatory domains and exerts opposing effects on dynein motility. PLoS One, 2017; 12: e0183672.

*11) Masukawa D, Koga M, Sezaki A, Nakao Y, Kamikubo Y, Hashimoto T, Okuyama-Oki Y, Aladeokin AC, Nakamura F, Yokoyama U, Wakui H, Ichinose H, Sakurai T, Umemura S, Tamura K, Ishikawa Y, Goshima Y: L-DOPA sensitizes vasomotor tone by modulating the vascular alpha1-adrenergic receptor. JCI Insight, 2017; 2: 90903.

12) Yamashita N, Joshi R, Zhang S, Zhang ZY, Kuruvilla R: Phospho-Regulation of Somato-Axon Transcytosis of Neurotrophin Receptors. Dev Cell, 2017; 42: 626-639.e5.

\section{Department of Gastroenterology}

〈Original Articles〉

1) Hojo M, Nagahara A, Asaoka D, Takeda T, Izumi K, Matsumoto K, Ueyama $\mathrm{H}$, Shimada Y, Matsumoto K, Nojiri S, Watanabe S: A Randomized, Double-Blind, Pilot Study of the Effect of Famotidine on Acotiamide Treatment for Functional Dyspepsia. Digestion, 2017; 96: 5-12.

2) Hojo M, Nagahara A, Asaoka D, Shimada Y, Sasaki H, Matsumoto K, Takeda T, Ueyama $\mathrm{H}$, Matsumoto K, Watanabe S: A Systematic Review of the Effectiveness of Antianxiety and Antidepressive Agents for Functional Dyspepsia. Intern Med, 2017; 56: 3127-3133.

3) Shibuya T, Nomura O, Kodani T, Murakami T, Fukushima H, Tajima Y, Matsumoto K, Ritsuno H, Ueyama H, Inami Y, Ishikawa D, Matsumoto K, Sakamoto N, Osada T, Nagahara A, Ogihara T, Watanabe S: Continuation of antithrombotic therapy may be associated with a high incidence of colonic post-polypectomy bleeding. Dig Endosc, 2017; 29: 314-321.

4) Asaoka D, Nagahara A, Hojo M, Matsumoto K, Ueyama H, Matsumoto K, Izumi K, Takeda T, Komori H, Akazawa Y, Shimada Y, Osada T, Watanabe S: Efficacy of a potassium-competitive acid blocker for improving symptoms in patients with reflux esophagitis, non-erosive reflux disease, and functional dyspepsia. Biomed Rep, 2017; 2: 175-180.

5) Kon K, Ikejima K, Morinaga M, Kusama H, Arai K, Aoyama T, Uchiyama A, Yamashina $\mathrm{S}$, Watanabe S: L-carnitine prevents metabolic steatohepatitis in obese diabetic KK-Ay mice. Hepatol Res, 2017; 47: E44-E54.

* 6) Aoyama T, Kuwahara-Arai K, Uchiyama A, Kon K, Yamashina S, Ikejima K, Kokubu S, Miyazaki A, Watanabe S: Spleen-derived lipocalin-2 in the portal vein regulates Kupffer cells activation and attenuates the development of liver fibrosis in mice. Lab Invest, 2017; 97: 890-902.

7) Ishikawa D, Sasaki T, Osada T, Kuwahara-Arai K, Haga K, Shibuya T, Hiramatsu $\mathrm{K}$, Watanabe S: Changes in Intestinal Microbiota Following Combination Therapy with Fecal Microbial Transplantation and 
Antibiotics for Ulcerative Colitis. Inflamm Bowel Dis, 2017; 1: 116-125.

8) Aoyama T, Takada H, Uchiyama A, Kon K, Yamashina S, Ikejima K, Ban H, Watanabe S: A Customized Online Nutrition Guidance System Is Effective for Treating Patients with Nonalcoholic Fatty Liver Disease by Supporting Continuity of Diet Therapy at Home: A Pilot Study. Intern Med, 2017; 13: 1651-1656.

9) Mori M, Genda T, Ichida T, Murata A, Kamei A, Tsuzura H, Sato S, Narita Y, Kanemitsu Y, Ishikawa S, Kikuchi T, Shimada Y, Hirano K, Iijima K, Sugimoto K, Wada R, Nagahara A, Watanabe S: Aldo-keto reductase family 1 member B10 is associated with hepatitis B virus-related hepatocellular carcinoma risk. Hepatol Res, 2017; 47: E85-E93.

10) Murakami T, Mitomi H, Yao T, Saitou T, Shibuya T, Watanabe S: Epigenetic regulation of Wnt/ $\beta$-catenin signal-associated genes in gastric neoplasia of the fundic gland (chief cell-predominant) type. Pathol Int, 2017; 67: 147-155.

11) Murakami $T$, Sakamoto $N$, Ritsuno $H$, Shibuya T, Osada T, Mitomi H, Yao T, Watanabe S: Distinct endoscopic characteristics of sessile serrated adenoma/polyp with and without dysplasia/carcinoma. Gastrointest Endosc, 2017; 85: 590-600.

12) Nomura O, Osada $T$, Shibuya $T$, Ishikawa $D$, Haga K, Kodani T, Sakamoto N, Ogihara T, Yamaji K, Watanabe S: Efficacy of cytapheresis for remission induction and dermatological manifestations of ulcerative colitis. J Clin Apher, 2017; 33: 21-28.

13) Takeda T, Asaoka D, Tajima $Y$, Matsumoto K, Takeda N, Hiromoto T, Okubo S, Saito H, Aoyama T, Shibuya T, Sakamoto N, Hojo M, Osada T, Nagahara A, Yao T, Watanabe S: Hemorrhagic polyps formed like fundic gland polyps during long-term proton pump inhibitor administration. Clin J Gastroenterol, 2017; 10: $478-484$.

14) Tajima $Y$, Murakami T, Saito T, Hiromoto T, Akazawa Y, Sasahara N, Mitomi H, Yao T, Watanabe S: Distinct Involvement of the Sonic Hedgehog Signaling Pathway in Gastric Adenocarcinoma of Fundic Gland Type and
Conventional Gastric Adenocarcinoma. Digestion, 2017; 96: 81-91.

15) Murakami T, Mitomi H, Yao T, Saito $T$, Shibuya T, Sakamoto N, Osada T, Watanabe S: Distinct histopathological characteristics in colorectal submucosal invasive carcinoma arising in sessile serrated adenoma/polyp and conventional tubular adenoma. Virchows Arch, 2017; 472: 383-393.

16) Takeda $T$, Asaoka D, Fukumura $Y$, Watanabe S: Asymptmatic giant retroperitoneal mass detected at a medical checkup. Clin Case Rep, 2017; 5: 2148-2150.

*17) Tomishima K, Sai JK, Kanazawa R, Miura H, Shimizu R, Sato K, Ishii S, Saito H, Ito T, Fukumura Y, Shiina S, Watanabe S: Impact of MUC1 Expression on the Progression of Intraductal Papillary Mucinous Neoplasm With Worrisome Features During Follow-up. Pancreas, 2017; 46: 1127-1132.

18) Kusama H, Kon K, Ikejima K, Arai K, Aoyama T, Uchiyama A, Yamashina S, Watanabe S: Sodium 4-phenylbutyric acid prevents murine acetaminophen hepatotoxicity by minimizing endoplasmic reticulum stress. J Gastroenterol, 2017; 52: 611-622.

19) Kitamura T, Ando H, Fukada H, Igusa $Y$, Kokubu S, Miyazaki A, Fujimura A, Shiina S, Watanabe S: Gadoxetic Acid-Enhanced MR Imaging Predicts Simeprevir-Induced Hyperbilirubinemia During Hepatitis C Virus Treatment: A Pilot Study. J Clin Pharmacol, 2017; 57: 369-375.

20) Genda T, Ichida T, Sakisaka S, Tanaka E, Mochida S, Ueno $\mathrm{Y}$, Inui $\mathrm{A}$, Egawa $\mathrm{H}$, Umeshita K, Furukawa H, Kawasaki S, Inomata Y: Survival in patients with ChildPugh class C cirrhosis: analysis of the liver transplant registry in Japan. Hepatol Res, 2017; 47: 1155-1164.

21) Matsuura K, Sawai H, Ikeo K, Ogawa S, Iio E, Isogawa M, Shimada N, Komori A, Toyoda $\mathrm{H}$, Kumada T, Namisaki T, Yoshiji H, Sakamoto N, Nakagawa M, Asahina Y, Kurosaki M, Izumi N, Enomoto N, Kusakabe A, Kajiwara E, Itoh Y, Ide T, Tamori A, Matsubara M, Kawada N, Shirabe K, Tomita E, Honda M, Kaneko S, Nishina S, Suetsugu A, Hiasa Y, Watanabe H, Genda T, Sakaida I, Nishiguchi 
S, Takaguchi K, Tanaka E, Sugihara J, Shimada M, Kondo Y, Kawai Y, Kojima K, Nagasaki M, Tokunaga K, Tanaka Y: Genome-wide Association Study Identifies TLL1 Variant Associated With Development of Hepatocellular Carcinoma After Eradication of Hepatitis C Virus Infection. Gastroenterology, 2017; 152: 1383-1394.

22) Nakao M, Nakayama N, Uchida Y, Tomiya T, Ido A, Sakaida I, Yokosuka O, Takikawa Y, Inoue K, Genda T, Shimizu M, Terai S, Tsubouchi H, Takikawa H, Mochida S: Nationwide survey for acute liver failure and late-onset hepatic failure in Japan. J Gastroenterol, Epub 2017 Oct 13.

23) Honda H, Takamura M, Yamagiwa S, Genda T, Horigome R, Kimura N, Setsu T, Tominaga K, Kamimura H, Matsuda Y, Wakai T, Aoyagi Y, Terai S: Overexpression of a disintegrin and metalloproteinase 21 is associated with motility, metastasis, and poor prognosis in hepatocellular carcinoma. Sci Rep, 2017; 7: 15485.

\section{Department of Cardiovascular Medicine}

〈Original Articles〉

* 1) Shimizu M, Miyazaki T, Takagi A, Sugita Y, Yatsu S, Murata A, Kato T, Suda S, Ouchi S, Aikawa T, Hiki M, Takahashi S, Hiki M, Hayashi H, Kasai T, Shimada K, Miyauchi K, Daida H: Low circulating coenzyme Q10 during acute phase is associated with inflammation, malnutrition, and in-hospital mortality in patients admitted to the coronary care unit. Heart Vessels, 2017; 32: 668-673.

* 2) Aikawa T, Miyazaki T, Shimada K, Sugita Y, Shimizu M, Ouchi S, Kadoguchi T, Yokoyama Y, Shiozawa T, Hiki M, Takahashi S, Al Shahi H, Dohi S, Amano A, Daida H: Low serum levels of EPA are associated with the size and growth rate of abdominal aortic aneurysm. J Atheroscler Thromb, 2017; 24: 912-920.

3) Matsushita K, Harada K, Miyazaki T, Miyamoto $\mathrm{T}$, Kohsaka S, Iida K, Tanimoto S, Yagawa M, Shiraishi Y, Yoshino H, Yamamoto T, Nagao K, Takayama M: Effect of heart failure secondary to ischemic cardiomyopathy on body weight and blood pressure. Am J Cardiol, 2017; 120: 1589-1594.
4) Ouchi S, Miyazaki T, Shimada K, Sugita Y, Shimizu M, Murata A, Kato T, Aikawa T, Suda S, Shiozawa T, Hiki M, Takahashi S, Iwata H, Kasai T, Miyauchi K, Daida H: Low docosahexaenoic acid, dihomo-gamma-linolenic acid, and arachidonic acid levels associated with long-term mortality in patients with acute decompensated heart failure in different nutritional statuses. Nutrients, 2017; 9: 956.

5) Shiraishi Y, Kohsaka S, Abe T, Harada K, Miyazaki T, Miyamoto T, Iida K, Tanimoto S, Yagawa M, Takei M, Nagatomo Y, Hosoda T, Yamamoto T, Nagao K, Takayama M; Tokyo CCU Network Scientific Committee: Impact of triggering events on outcomes of acute heart failure. Am J Med, Epub 2017 Sep 20.

6) Ueno Y, Tanaka R, Yamashiro K, Miyamoto N, Hira K, Kurita N, Sakurai M, Urabe T, Shimada K, Miyazaki T, Daida H, Hattori N: Age Stratification and Impact of Eicosapentaenoic Acid and Docosahexaenoic Acid to Arachidonic Acid Ratios in Ischemic Stroke Patients. J Atheroscler Thromb, Epub 2017 Dec 2.

7) Wada H, Dohi T, Miyauchi K, Doi S, Naito R, Konishi H, Tsuboi S, Ogita M, Kasai T, Hassan A, Okazaki S, Isoda K, Suwa S, Daida H: Prognostic Impact of the Geriatric Nutritional Risk Index on Long-Term Outcomes in Patients Who Underwent Percutaneous Coronary Intervention. Am J Cardiol, 2017; 119: 1740-1745.

8) Okai I, Dohi T, Okazaki S, Jujo K, Nakashima M, Otsuki H, Tanaka K, Arashi H, Okabe R, Nagura F, Nara Y, Tamura H, Kurata T, Kawashima H, Kyono H, Yamaguchi J, Miyauchi K, Kozuma K, Hagiwara N, Daida H: Clinical Characteristics and Long-Term Outcomes of Rotational Atherectomy - J2T Multicenter Registry. Circ J, Epub 2017 Sep 21.

9) Ouchi S, Shimada K, Miyazaki T, Takahashi S, Sugita Y, Shimizu M, Murata A, Kadoguchi T, Kato T, Aikawa T, Suda S, Sai E, Hiki M, Iwata H, Kasai T, Miyauchi K, Daida H: Low 1,5-anhydroglucitol levels are associated with long-term cardiac mortality in acute coronary syndrome patients with hemoglobin Alc 
levels less than 7.0. Cardiovasc Diabetol, 2017; 16: 151.

10) Wada H, Dohi T, Miyauchi K, Shitara J, Endo H, Doi S, Konishi H, Naito R, Tsuboi S, Ogita M, Kasai T, Hassan A, Okazaki S, Isoda K, Suwa S, Daida H: Pre-procedural neutrophilto-lymphocyte ratio and long-term cardiac outcomes after percutaneous coronary intervention for stable coronary artery disease. Atherosclerosis, 2017; 265: 35-40.

11) Dai Y, Yang J, Takagi A, Konishi H, Miyazaki T, Masuda H, Shimada K, Miyauchi K, Daida $\mathrm{H}$ : In-hospital and long-term outcomes of congestive heart failure: Predictive value of B-type and amino-terminal pro-B-type natriuretic peptides and their ratio. Exp Ther Med, 2017; 14: 1715-1721.

12) Takasu K, Miyazaki T, Negoro K, Yatsu S, Shimizu M, Murata A, Kato T, Suda S, Hiki M, Kasai T, Miyauchi K, Daida H: Successful Treatment of Congestive Heart Failure Due to Severe Aortic Valve Stenosis with Low Dose Tolvaptan in Elderly Patients. Int Heart J, 2017; 58: 378-384.

13) Takahashi C, Kurano M, Nishikawa M, Kano K, Dohi T, Miyauchi K, Daida H, Shimizu T, Aoki J, Yatomi Y: Vehicle-dependent Effects of Sphingosine 1-phosphate on Plasminogen Activator Inhibitor-1 Expression. J Atheroscler Thromb, 2017; 24: 954-969.

14) Naito R, Miyauchi K, Konishi H, Tsuboi S, Ogita M, Dohi T, Kasai T, Tamura H, Okazaki S, Isoda K, Daida H: Clinical Outcomes in Diabetic Patients Who Underwent Percutaneous Coronary Intervention during the Plain Old Balloon Angioplasty (POBA)-, Bare Metal Stents (BMS) - and Drug-eluting Stents (DES)-eras from 1984 to 2010. Intern Med, 2017; 56: 1-9.

15) Shiomi H, Morimoto T, Kitaguchi S, Nakagawa Y, Ishii K, Haruna Y, Takamisawa I, Motooka M, Nakao K, Matsuda S, Mimoto S, Aoyama Y, Takeda T, Murata K, Akao M, Inada T, Eizawa H, Hyakuna E, Awano K, Shirotani M, Furukawa Y, Kadota K, Miyauchi K, Tanaka M, Noguchi Y, Nakamura S, Yasuda S, Miyazaki S, Daida H, Kimura K, Ikari Y, Hirayama H, Sumiyoshi T, Kimura T; ReACT Investigators: The ReACT Trial:
Randomized Evaluation of Routine Follow-up Coronary Angiography After Percutaneous Coronary Intervention Trial. JACC Cardiovasc Interv, 2017; 10: 109-117.

16) Kurano M, Kano K, Dohi T, Matsumoto H, Igarashi K, Nishikawa M, Ohkawa R, Ikeda H, Miyauchi K, Daida H, Aoki J, Yatomi Y: Different origins of lysophospholipid mediators between coronary and peripheral arteries in acute coronary syndrome. J Lipid Res, 2017; 58: 433-442.

17) Hassan A, Dohi T, Miyauchi K, Ogita M, Kurano M, Ohkawa R, Nakamura K, Tamura H, Isoda K, Okazaki S, Yatomi Y, Daida H: Prognostic impact of homocysteine levels and homocysteine thiolactonase activity on longterm clinical outcomes in patients undergoing percutaneous coronary intervention. J Cardiol, 2017; 69: 830-835.

18) Kuramitsu S, Miyauchi K, Yokoi H, Suwa S, Nishizaki Y, Yokoyama T, Nojiri S, Iwabuchi M, Shirai S, Ando K, Okazaki S, Tamura H, Watada H, Daida H: Effect of sitagliptin on plaque changes in coronary artery following acute coronary syndrome in diabetic patients: The ESPECIAL-ACS study. J Cardiol, 2017; 69: 369-376.

19) Wada H, Ogita M, Miyauchi K, Shitara J, Endo H, Doi S, Naito R, Konishi H, Tsuboi S, Dohi T, Kasai T, Tamura H, Okazaki S, Isoda K, Suwa $\mathrm{S}$, Daida H: Impact of gender difference on long-term outcomes of percutaneous coronary intervention for coronary artery disease in patients under statin treatment. Heart Vessels, 2017; 32: 16-21.

20) Ri K, Kumamaru KK, Fujimoto S, Kawaguchi Y, Dohi T, Yamada S, Takamura K, Kogure Y, Yamada N, Kato E, Irie R, Takamura T, Suzuki M, Hori M, Aoki S, Daida H: Noninvasive Computed Tomography-Derived Fractional Flow Reserve Based on Structural and Fluid Analysis: Reproducibility of On-site Determination by Unexperienced Observers. J Comput Assist Tomogr, Epub 2017 Sep 20.

21) Chung WJ, Soga Y, Tomoi Y, Fujihara M, Okazaki S, Yamauchi Y, Shintani Y, Suzuki K; SCALLOP Investigators: Clinical Impact of Intravascular Ultrasound Guidance During Endovascular Treatment of Subclavian 
Artery Disease. J Endovasc Ther, 2017; 24: 731-738.

22) Kamioka N, Soga Y, Kuramitsu S, Iida O, Hirano K, Suzuki K, Kawasaki D, Yamaoka T, Suematsu N, Shintani Y, Miyashita Y, Takahashi H, Tsuchiya T, Shinozaki N, Okazaki S, Ando K: Clinical outcomes of balloon angioplasty alone versus nitinol stent implantation in patients with small femoropopliteal artery disease: Observations from the Retrospective Multicenter Analysis for Femoropopliteal Stenting (REAL-FP). Catheter Cardiovasc Interv, 2017; 90: 790-797.

23) Suzuki K, Mizutani Y, Soga Y, Iida O, Kawasaki D, Yamauchi Y, Hirano K, Koshida R, Kamoi D, Tazaki J, Higashitani M, Shintani Y, Yamaoka T, Okazaki S, Suematsu N, Tsuchiya T, Miyashita Y, Shinozaki N, Takahashi H, Inoue N: Efficacy and Safety of Endovascular Therapy for Aortoiliac TASC D Lesions. Angiology, 2017; 68: 67-73.

24) Okai I, Iwata H, Osborn EA, Fukuda K, Shiozaki M, Kimura Y, Chikata Y, Inoue K, Fujiwara Y, Jaffer FA, Daida H, Sumiyoshi M: Sequential Acute Coronary Syndrome 4 Days Apart: A Missed Opportunity? Circ J, 2017; 81: 1231-1233.

25) Wada H, Ogita M, Miyauchi K, Tsuboi S, Konishi H, Shitara J, Kunimoto M, Sonoda T, Iso T, Ebina H, Aoki E, Kitamura K, Tamura H, Suwa S, Daida H: Contemporary sex differences among patients with acute coronary syndrome treated by emergency percutaneous coronary intervention. Cardiovasc Interv Ther, 2017; 32: 333-340.

26) Goettsch C, Iwata H, Hutcheson JD, O'Donnell CJ, Chapurlat R, Cook NR, Aikawa M, Szulc P, Aikawa E: Serum Sortilin Associates with Aortic Calcification and Cardiovascular Risk in Men. Arterioscler Thromb Vasc Biol, 2017; 37: 1005-1011.

27) Ohsaka H, Omori K, Takeuchi I, Jitsuiki K, Yoshizawa T, Ishikawa K, Isoda K, Suwa S, Yanagawa Y: Acute Coronary Syndrome Evacuated by a Helicopter from the Scene. Air Med J, 2017; 36: 179-181.

28) Takahashi N, Isoda K, Hiki M, Fujimoto S, Daida H: Thrombolytic Therapy and Aspiration of Clots were Effective in the Removal of a Transient Inferior Vena Cava (IVC) Filter that Captured a Large Thrombus. Intern Med, 2017; 56: 1369-1373.

29) Fujino M, Ishihara M, Ogawa $H$, Nakao K, Yasuda S, Noguchi T, Ozaki Y, Kimura K, Suwa S, Fujimoto K, Nakama Y, Morita T, Shimizu W, Saito Y, Hirohata A, Morita Y, Inoue $\mathrm{T}$, Okamura $\mathrm{A}$, Uematsu $\mathrm{M}$, Ako J, Nakai M, Nishimura K, Miyamoto Y; JMINUET Investigators: Impact of symptom presentation on in-hospital outcomes in patients with acute myocardial infaction. J Cardiol, 2017; 70: 29-34.

30) Kuji S, Kosuge M, Kimura K, Nakao K, Ozaki Y, Ako J, Noguchi T, Yasuda S, Suwa S, Fujimoto K, Nakama Y, Morita T, Shimizu W, Saito Y, Hirohata A, Morita Y, Inoue T, Nishimura K, Miyamoto Y, Ishihara M; JMINUET Investigators: Impact of acute kidney injury on in-hospital outcomes of patients with acute myocardial infarctionResults from the J-MINUET substudy. Circ J, 2017; 81: 733-739.

31) Ishihara M, Nakao K, Ozaki Y, Kimura K, Ako J, Noguchi T, Fujino M, Yasuda S, Suwa S, Fujimoto K, Nakama Y, Morita T, Shimizu W, Saito Y, Hirohata A, Morita Y, Inoue T, Okamura A, Uematsu M, Hirata K, Tanabe K, Shibata Y, Owa M, TsujitaK, Funayama H, Kokubu N, Kozuma K, Tobaru T, Oshima S, Nakai M, Nishimura K, Miyamoto Y, Ogawa $\mathrm{H}$; J-MINUET Investigators: Long-term outcomes of non-ST-elevation myocardial infarction without creatine kinase elevation The J-MINUET study. Cir J, 2017; 81: 958965.

32) Ogita M, Suwa S, Ebina H, Nakao K, Ozaki Y, Kimura K, Ako J, Noguchi T, Yasuda S, Fujimoto K, Nakama Y, Morita T, Shimizu W, Saito Y, Hirohata A, Morita Y, Inoue T, Okamura A, Uematsu M, Hirata K, Tanabe K, Shibata Y, Owa M, Hokimoto S, Funayama H, Kokubo N, Kozuma K, Uemura S, Tobaru T, Saku K, Oshima S, Nishimura K, Miyamoto Y, Ishihara M; J-MINUET investigators: Offhours presentation does not affect in-hospital mortality of Japanese patients with acute myocardial infarction: J-MINUET substudy. J Cardiol, 2017; 70: 553-558. 
33) Ohsaka H, Omori K, Takeuchi I, Jitsuiki K, Yoshizawa T, Ishikawa K, Isoda K, Suwa S, Yanagawa Y: Acute coronary syndrome evacuated by a helicopter from the scene. Air Med J, 2017; 36: 170-181.

34) Nishida K, Nakatsuma K, Shiomi H, Natsuaki M, Kawai K, Morimoto T, Kozuma K, Igarashi K, Kadota K, Tanabe K, Morino Y, Hibi K, Akasaka T, Abe M, Suwa S, Muramatsu T, Kobayashi M, Dai K, Nakao K, Tarutani Y, Fujii K, Kimura T; RESET and NEXT investigators: Second-Generation vs. FirstGeneration Drug-Eluting Stents in Patients With Calcified Coronary Lesions - Pooled Analysis From the RESET and NEXT Trials. Circ J, Epub 2017 Oct 5.

35) Hashimoto T, Ako J, Nakao K, Ozaki Y, Kimura K, Ako J, Noguchi T, Yasuda S, Suwa S, Fujimoto K, Nakama Y, Morita T, Shimizu W, Saito Y, Hirohata A, Morita Y, Inoue T, Okamura A, Uematsu M, Hirata K, Tanabe K, Shibata Y, Owa M, Tsujita K, Funayama H, Kokubo N, Kozuma K, Uemura S, Tobaru T, Saku K, Oshima S, Nakai M, Nishimura K, Miyamoto Y, Ogawa H, Ishihara M; JMINUET investigators: A low eicosapentaenoic acid/arachidonic acid ratio is associated with in-hospital fatal arrhythmic events in patients with acute myocardial infarction: a J-MINUET substudy. Heart Vessels, Epub 2017 Nov 16.

36) Akita K, Isoda K, Sato-Okabayashi Y, Kadoguchi T, Kitamura K, Ohtomo F, Shimada K, Daida H: An interleukin-6 receptor antibody suppresses atherosclerosis in atherogenic mice. Front Cardiovasc Med, 2017; 4: 84.

37) Kawamoto H, Ruparelia N, Latib A, Miyazaki T, Sato K, Tanaka A, Naganuma T, Sticchi A, Chieffo A, Carlino M, Montorfano M, Colombo A: Expansion in calcific lesions and overall clinical outcomes following bioresorbable scaffold implantation optimized with intravascular ultrasound. Catheter Cardiovasc Interv, 2017; 89: 789-797.

38) Tanaka A, Latib A, Kawamoto H, Jabbour RJ, Sato K, Miyazaki T, Naganuma T, Mangieri A, Pagnesi M, Montalto C, Chieffo A, Carlino M, Montorfano M, Colombo A: Clinical outcomes of a real-world cohort following bioresorbable vascular scaffold implantation utilising an optimised implantation strategy. EuroIntervention, 2017; 12: 1730-1737.

39) Wada H, Dohi T, Miyauchi K, Shitara J, Endo H, Doi S, Naito R, Konishi H, Tsuboi S, Ogita M, Kasai T, Hassan A, Okazaki S, Isoda K, Shimada K, Suwa S, Daida H: Preprocedural High-Sensitivity C-Reactive Protein Predicts Long-Term Outcome of Percutaneous Coronary Intervention. Circ J, 2017; 81: 90-95.

40) Wada H, Dohi T, Miyauchi K, Doi S, Naito R, Konishi H, Tsuboi S, Ogita M, Kasai T, Okazaki S, Isoda K, Suwa S, Daida H: Independent and Combined Effects of Serum Albumin and C-Reactive Protein on LongTerm Outcomes of Patients Undergoing Percutaneous Coronary Intervention. Circ J, 2017; 81: 1293-1300.

41) Wada H, Dohi T, Miyauchi K, Doi S, Konishi H, Naito R, Tsuboi S, Ogita M, Kasai T, Okazaki S, Isoda K, Suwa S, Daida H: Prognostic impact of nutritional status assessed by the Controlling Nutritional Status score in patients with stable coronary artery disease undergoing percutaneous coronary intervention. Clin Res Cardiol, 2017; 106: 875-883.

42) Shiozaki M, Inoue K, Suwa S, Chien-Chang Lee, Chikata Y, Ishiura J, Kimura Y, Fukuda K, Tamura H, Fujiwara Y, Sumiyoshi M, Daida H: Utility of the 0-hour/1-hour highsensitivity cardiac troponin $\mathrm{T}$ algorithm in Asian patients with suspected non-ST elevation myocardial infarction. Int J Cardiol, 2017; 249: $32-35$.

$\uparrow 43$ ) Kattel S, Kasai T, Matsumoto H, Yatsu S, Murata A, Kato T, Suda S, Hiki M, Takagi A, Daida H: Association between elevated blood glucose level on admission and long-term mortality in patients with acute decompensated heart failure. J Cardiol, 2017; 69; 619624.

44) Lyons OD, Floras JS, Logan AG, Beanlands R, Durán Cantolla J, Fitzpatrick M, Fleetham J, Kimoff RJ, Leung RST, Lorenzi Filho G, Mayer P, Morrison DL, Ryan CM, Series F, Tomlinson GA, Woo A, Arzt M, Parthasarathy S, Redolfi S, Kasai T, Parati G, Delgado $\mathrm{DH}$, Bradley TD, for the ADVENT-HF 
Investigators: Design of the Effect of Adaptive Servo Ventilation on Survival and Cardiovascular Hospital Admissions in Patients with Heart Failure and Sleep Apnea: The ADVENT-HF Trial. Eur J Heart Fail, 2017; 19: 579-587.

* 45) Yatsu S, Kasai T, Suda S, Matsumoto H, Shiroshita N, Kato M, Kawana F, Murata A, Kato T, Hiki M, Daida H: Impact of periodic leg movements during sleep in hospitalized patients following acute decompensated heart failure on clinical outcomes. Circ J, 2017; 81: $495-500$.

*46) Shimizu M, Miyazaki T, Takagi A, Kato T, Suda S, Hiki M, Hiki M, Hayashi H, Kasai T, Shimada K, Miyauchi K, Daida H: Low serum coenzyme Q10 during acute phase in the coronary care unit is associated with inhospital mortality. Heart Vessels, 2017; 32: 668-673.

47) Ouchi S, Miyazaki T, Shimada K, Sugita Y, Shimizu M, Murata A, Kato T, Aikawa T, Suda S, Shiozawa T, Hiki M, Takahashi S, Iwata H, Kasai T, Miyauchi K, Daida H: Low polyunsaturated fatty acid levels predict long-term mortality in patients with acute decompensated heart failure independent of nutritional status. Nutrients, 2017; 9: pii: E956.

48) Perger E, Inami T, Lyons OD, Alshaer H, Smith S, Floras JS, Logan AG, Arzt M, Duran Cantolla J, Delgado D, Fitzpatrick M, Fleetham J, Kasai T, Kimoff, JR, Leung RST, Lorenzi Filho G, Mayer P, Mielniczuk L, Morrison DL, Parati G, Parthasarathy S, Redolfi S, Ryan CM, Series F, Tomlinson GA, Woo A, Bradly TD for the ADVENT-HF Investigators: Distinct patterns of hyperpnea during Cheyne-Stokes respiration: implication for cardiac function in patients with heart failure. J Clin Sleep Med, 2017; 13: 1235-1241.

* 49) Kato T, Kasai T, Yatsu S, Murata A, Matsumoto H, Suda S, Hiki M, Shiroshita N, Kato M, Kawana F, Miyazaki S, Daida H: Acute effects of positive airway pressure on functional mitral regurgitation in patients with systolic heart failure. Front Physiol, 2017; 8: 921.

50) Wada H, Dohi T, Miyauchi K, Shitara J, Endo
H, Doi S, Naito R, Konishi H, Tsuboi S, Ogita M, Kasai T, Okazaki S, Isoda K, Shimada K, Suwa S, Daida H: Impact of serum albumin levels on long-term outcomes in patients undergoing percutaneous coronary intervention. Heart Vessels, 2017; 32: 1085-1092.

51) Ohmura H, Fukushima Y, Mizuno A, Niwa K, Kobayashi Y, Ebina T, Kimura K, Ishibashi S, Daida H; Research Committee on Primary Hyperlipidemia of the Ministry of Health and Welfare of Japan: Estimated Prevalence of Heterozygous Familial Hypercholesterolemia in Patients with Acute Coronary Syndrome: Multicenter Registration Study in Japan. Int Heart J, 2017; 58: 88-94.

*52) Hiki M, Miyazaki T, Shimada K, Sugita Y, Shimizu M, Aikawa T, Ouchi S, Shiozawa T, Takasu K, Takahashi S, Takagi A, Miyauchi K, Daida H: Significance of Serum Polyunsaturated Fatty Acid Level Imbalance in Patients with Acute Venous Thromboembolism. J Atheroscler Thromb, 2017; 24: 10161022.

53) Takano A, Sekita G, Watanabe M, Mukaida H, Komatsu S, Tabuchi H, Hayashi H, Tokano T, Sumiyoshi M, Nakazato K, Daida H: Longterm reliability of sweet-tip type screw-in leads. J Arrhythmia, 2017; 33: 12-16.

54) Komatsu S, Sumiyoshi M, Miura S, Kimura Y, Shiozawa T, Hirano K, Odagiri F, Tabuchi H, Hayashi H, Sekita G, Tokano T, Nakazato K, Daida H: A proposal of clinical ECG index "vagal score" for determining the mechanism of paroxysmal atrioventricular block. J Arrhythmia, 2017; 33: 208-213.

*55) Shiozawa T, Shimada K, Sekita G, Hayashi H, Tabuchi H, Miura S, Fujimoto S, Kadoguchi T, Ouchi S, Aikawa T, Shahi HA, Takahashi S, Miyazaki T, Sumiyoshi M, Nakazato K, Daida $\mathrm{H}$ : Left atrial appendage volume and plasma docosahexaenoic acid levels are associated with fibrillation recurrence after catheter ablation. Cardiol Res, 2017; 8: 96-104.

56) Okai I, Iwata H, Osborn EA, Fukuda K, Shiozaki M, Kimura Y, Chikata Y, Inoue K, Fujiwara Y, Jaffer FA, Daida H, Sumiyoshi M: Sequential acute coronary syndrome 4 days apart: a missed opportunity? Circ J, 2017; 81: 1231-1233. 
* 57) Aikawa T, Miyazaki T, Shimada K, Sugita Y, Shimizu M, Ouchi S, Kadoguchi T, Yokoyama Y, Shiozawa T, Hiki M, Takahashi S, Al Shahi H, Dohi S, Amano A, Daida H: Low Serum Levels of EPA are Associated with the Size and Growth Rate of Abdominal Aortic Aneurysm. J Atheroscler Thromb, 2017; 24: 912-920.

58) Hirose K, Daimon M, Miyazaki S, Chiang SJ, Morimoto-Ichikawa R, Maruyama M, Kawata T, Ohmura H, Daida H: Estrogen variation during the menstrual cycle does not influence left ventricular diastolic function and untwisting rate in premenopausal women. J Cardiol, 2017; 69: 389-393.

59) Suwa S, Ogita M, Miyauchi K, Sonoda T, Konishi H, Tsuboi S, Wada H, Naito R, Dohi T, Kasai T, Okazaki S, Isoda K, Daida H: Impact of Lipoprotein(a) on Long-Term Outcomes in Patients with Coronary Artery Disease Treated with Statin After a First Percutaneous Coronary Intervention. J Atheroscler Thromb, 2017; 24: 1125-1131.

*60) Ouchi S, Miyazaki T, Shimada K, Sugita Y, Shimizu M, Murata A, Kato T, Aikawa T, Suda S, Shiozawa T, Hiki M, Takahashi S, Kasai T, Miyauchi K, Daida H: Decreased circulating dihomo-gamma-linolenic acid levels are associated with total mortality in patients with acute cardiovascular disease and acute decompensated heart failure. Lipids Health Dis, 2017; 16: 150.

61) Takagi H, Morio $Y$, Ishiwata $T$, Shimada $K$, Kume A, Miura K, Kuwasaki E, Kato M, Seyama K, Takahashi K: Effect of telling patients their "spirometric-lung-age" on smoking cessation in Japanese smokers. J Thorac Dis, 2017; 9: 5052-5060.

62) Arao K, Yasu T, Endo Y, Funazaki T, Ota Y, Shimada K, Tokutake E, Naito N, Takase B, Wake M, Ikeda N, Horie Y, Sugimura H, Momomura S, Kawakami M: Investigators of the Anti-Arteriosclerosis and Lipid Lowering with Pitavastatin Evaluation Study in Nippon (ALPEN). Effects of pitavastatin on walking capacity and CD34+/133+ cell number in patients with peripheral artery disease. Heart Vessels, 2017; 32: 1186-1194.

*63) Aikawa T, Miyazaki T, Shimada K, Sugita Y,
Shimizu M, Ouchi S, Kadoguchi T, Yokoyama Y, Shiozawa T, Hiki M, Takahashi S, Al Shahi H, Dohi S, Amano A, Daida H: Low EPA/AA ratio is associated with the size and growth rate of abdominal aortic aneurysm. J Atheroscler Thromb, 2017; 24: 912-920.

*64) Kaga H, Tamura Y, Takeno K, Kakehi S, Funayama T, Furukawa Y, NishitaniYokoyama M, Shimada K, Daida H, Aoki S, Giacca A, Kanazawa A, Kawamori R, Watada $\mathrm{H}$ : Correlates of insulin clearance in apparently healthy non-obese Japanese men. Sci Rep, 2017; 7: 1462.

65) Hata J, Nagai A, Hirata M, Kamatani Y, Tamakoshi A, Yamagata Z, Muto K, Matsuda K, Kubo M, Nakamura Y; Biobank Japan Cooperative Hospital Group, Kiyohara Y, Ninomiya T: Risk prediction models for mortality in patients with cardiovascular disease: The BioBank Japan project. J Epidemiol, 2017; 3S: S71-S76.

*66) Sai E, Shimada K, Yokoyama T, Hiki M, Sato S, Hamasaki N, Maruyama M, Morimoto R, Miyazaki T, Fujimoto S, Tamura Y, Aoki S, Watada H, Kawamori R, Daida H: Myocardial triglyceride content in patients with left ventricular hypertrophy: Comparison between hypertensive heart disease and hypertrophic cardiomyopathy. Heart Vessels, 2017; 32: 166-174.

67) Takahashi M, Ando J, Shimada K, Nishizaki Y, Tani S, Ogawa T, Yamamoto M, Nagao K, Hirayama A, Yoshimura M, Daida H, Nagai R, Komuro I: The ratio of serum $n-3$ to $n-6$ polyunsaturated fatty acids is associated with diabetes mellitus in patients with prior myocardial infarction: a multicenter cross $^{-}$ sectional study. BMC Cardiovasc Disord, 2017; 17: 41.

68) Ko BS, Cameron JD, Munnur RK, Wong DT, Fujisawa Y, Sakaguchi T, Hirohata K, HislopJambrich J, Fujimoto S, Takamura K, Crossett M, Leung M, Kuganesan A, Malaiapan Y, Nasis A, Troupis J, Meredith IT, Seneviratne SK: Noninvasive CT-Derived FFR Based on Structural and Fluid Analysis: A Comparison With Invasive FFR for Detection of Functionally Significant Stenosis. JACC Cardiovasc Imaging, 2017; 10: 663-673. 
69) Takamura K, Fujimoto S, Kondo T, Hiki M, Kawaguchi Y, Kato E, Daida H: Incremental Prognostic Value of Coronary Computed Tomography Angiography: High-Risk Plaque Characteristics in Asymptomatic Patients. J Atheroscler Thromb, 2017; 24: 1174-1185.

$\langle$ Reviews〉

1) Naito R, Miyauchi K: Coronary artery disease and type 2 diabetes mellitus: Current treatment strategies and future perspective. Int Heart J, 2017; 58: 475-480.

2) Naito R, Miyauchi K, Daida H: Racial Differences in the Cholesterol-Lowering Effect of Statin. J Atheroscler Thromb, 2017; 24: 1925.

3) Wada H, Mattson PC, Iwata H: Stent or Scaffold thrombosis: past, current, and future perspectives. EMJ Int Cradiol, 2017; 5: 55-61.

4) Akashiba $T$, Ishikawa $Y$, Ishihara $H$, Imanaka H, Ohi M, Ochiai R, Kasai T, Kimura K, Kondoh Y, Sakurai S, Shime N, Suzukawa M, Takegami M, Takeda S, Tasaka S, Taniguchi H, Chohnabayashi N, Chin K, Tsuboi T, Tomii K, Narui K, Hasegawa N, Hasegawa R, Ujike Y, Kubo K, Hasegawa Y, Momomura SI, Yamada Y, Yoshida M, Takekawa Y, Tachikawa R, Hamada S, Murase K: The Japanese Respiratory Society Noninvasive Positive Pressure Ventilation (NPPV) Guidelines (second revised edition). Respir Investig, 2017; 55: 83-92.

5) Murata A, Kasai T: Do the blood pressure changes in association with continuous positive airway pressure compliance play an important role to improve cardiovascular outcomes? J Thorac Dis, 2017; 9: 2255-2258.

6) Kasai T: Sleep-disordered breathing and cardiovascular disease: an epiphenomenon or a causal relationship? Sleep Biol Rhythms, 2017; 15: 259-260.

7) Sumiyoshi M: Driving restriction for patients with reflex syncope. J Arrhythmia 2017; 30: 590-593.

8) Nishizaki Y, Shimada K, Daida H: The Balance of Omega-3 Polyunsaturated Fatty Acids for Reducing Residual Risks in Patients with Coronary Artery Disease. Acta Cardiologica, 2017; 72: 240-248.

9) Koh KK, Sakuma I, Shimada K, Hayashi T,
Quon MJ: Combining potent statin therapy with other drugs to optimize simultaneous cardiovascular and metabolic benefits while minimizing adverse events. Korean Circ J, 2017; 47: 432-439.

\section{Department of Respiratory Medicine}

〈Original Articles〉

1) Sandhu Y, Ando K, Takekawa H, Takagi H, Hirama M, Kido K, Takahashi K: Safety of Bronchoscopy for Patients Undergoing Hemodialysis. Respir Investig, 2017; 55: 173175.

2) Namba $Y$, Togo S, Tulafu M, Kadoya K, Nagahama KY, Taka H, Kaga N, Orimo A, Liu $\mathrm{XD}$, Takahashi K: Combination of glycopyrronium and indacaterol inhibits carbacholinduced ERK5 signal in fibrotic processes. Respir Res, 2017; 18: 46.

3) Ishimori A, Harada N, Chiba A, Harada S, Matsuno K, Makino F, Ito J, Ohta S, Ono J, Atsuta R, Izuhara K, Takahashi K, Miyake S: Circulating activated innate lymphoid cells and mucosal-associated invariant $\mathrm{T}$ cells are associated with airflow limitation in patients with asthma. Allergol Int, 2017; 66: 302-309.

4) Ai T, Yuri M, Tabe Y, Kakimoto A, Morishita S, Tsuchiya K, Takamochi K, Kodama Y, Takahashi F, Shigeki M, Horii T, Suzuki K, Takahashi K, Miida T, Ohsaka A: Comparison of the Analytical Performance Between cobas EGFR Assay and PCR-Clamp Method in the Detection of EGFR Mutations in Japanese Non-Small Cell Lung Cancer Patients. Clin Lab, 2017; 63: 1021-1026.

5) Nakamura K, Kato M, Shukuya T, Mori K, Sekimoto Y, Ihara H, Kanemaru R, Ko R, Shibayama R, Tajima K, Koyama R, Shimada N, Nagashima O, Takahashi F, Sasaki S, Takahashi K: Surfactant protein-D predicts prognosis of interstitial lung disease induced by anticancer agents in advanced lung cancer: a case control study. BMC Cancer, 2017; 17: 302.

6) Togo S, Katagiri N, Namba Y, Tulafu M, Nagahama K, Kadoya K, Takamochi K, Oh S, Suzuki K, Sakurai F, Mizuguchi H, Urata Y, Takahashi K: Sensitive detection of viable circulating tumor cells using a novel 
conditionally telomerase-selective replicating adenovirus in non-small cell lung cancer patients. Oncotarget, 2017; 8: 34884-34895.

7) Asao T, Fujiwara Y, Itahashi K, Kitahara S, Goto Y, Horinouchi H, Kanda S, Nokihara H, Yamamoto N, Takahashi K, Ohe Y: Sequential Use of Anaplastic Lymphoma Kinase Inhibitors in Japanese Patients with ALKRearranged Non-Small-Cell Lung Cancer: A Retrospective Analysis. Clin Lung Cancer, 2017; 18: e251-e258.

8) Yoshikawa H, Fujii M, Iwakami SI, Takeda I, Hayakawa D, Takahashi K: Chylothorax ascribed to chronic heart failure in a woman of very advanced years. Geriatr Gerontol Int, 2017; 17: 1133-1135.

9) Takaeshige T, Harada N, Sekimoto Y, Kanemaru R, Tsutsumi T, Matsuno K, Shiota S, Masuda A, Gotoh A, Asahina M, Uekusa T, Takahashi K: Pulmonary Intravascular large B-cell lymphoma (IVLBCL) disguised as an Asthma exacerbation in a patient with asthma. Intern Med, 2017; 56: 1885-1891.

10) Nurwidya F, Takahashi F, Kato M, Baskoro $\mathrm{H}$, Hidayat M, Wirawan A, Takahashi K: CD44 silencing decreases the expression of stem cell-related factors induced by transforming growth factor $\beta 1$ and tumor necrosis factor $\alpha$ in lung cancer: Preliminary findings. Bosn J Basic Med Sci, 2017; 17: 228-234.

11) Honma $Y$, Togo S, Shimizu K, Tulafu M, Hayashi T, Uekusa T, Tominaga S, Kido K, Fujimoto Y, Nanba Y, Takamochi K, Oh S, Suzuki K, Takahashi K: Expression of thymidylate synthase predicts clinical outcomes of S-1-based chemotherapy in squamous cell lung cancer. Oncol Lett, 2017; 14: 3319-3326.

12) Hara M, Iwakami S, Sasaki S, Fujii M, Takahashi K: A Retrospective analysis of prognostic factors of nursing and healthcareassociated pneumonia. Juntendo Medical Journal, 2017; 63: 354-361.

*13) Suzuki Y, Sato T, Sugimoto M, Baskoro H, Karasutani K, Mitsui A, Nurwidya F, Arano N, Kodama Y, Hirano SI, Ishigami A, Seyama K, Takahashi K: Hydrogen-rich pure water prevents cigarette smoke-induced pulmonary emphysema in SMP30 knockout mice. Biochem Biophys Res Commun, 2017; 492:
74-81.

14) Kodama Y, Kishimoto $Y$, Muramatsu $Y$, Tatebe J, Yamamoto Y, Hirota N, Itoigawa Y, Atsuta R, Koike K, Sato T, Aizawa K, Takahashi K, Morita T, Homma S, Seyama K, Ishigami A: Antioxidant nutrients in plasma of Japanese patients with chronic obstructive pulmonary disease (COPD), asthma-COPD overlap syndrome, and bronchial asthma. Clin Respir J, 2017; 11: 915-924.

15) Kohsaka S, Nagano M, Ueno T, Suehara Y, Hayashi T, Shimada N, Takahashi K, Suzuki K, Takamochi K, Takahashi F, Mano H: A method of high-throughput functional evaluation of EGFR gene variants of unknown significance in cancer. Sci Transl Med, 2017; 9. pii: eaan6566.

16) Tobino K, Hirai T, Johkoh T, Fujimoto K, Kawaguchi A, Tomiyama N, Takahashi K, Seyama K: Difference of the progression of pulmonary cysts assessed by computed tomography among COPD, lymphangioleiomyomatosis, and Birt-Hogg-Dubé syndrome. PLoS One, 2017; 12: e0188771.

17) Takagi H, Morio $Y$, Ishiwata $T$, Shimada $K$, Kume A, Miura K, Kuwasaki E, Kato M, Seyama K, Takahashi K: Effect of telling patients their "spirometric-lung-age" on smoking cessation in Japanese smokers. J Thorac Dis, 2017; 9: 5052-5060.

18) Isshiki T, Akiba H, Nakayama M, Harada N, Okumura K, Homma S, Miyake S: Cutting Edge: Anti-TIM-3 Treatment Exacerbates Pulmonary Inflammation and Fibrosis in Mice. J Immunol, 2017; 199: 3733-3737.

*19) Ishimori A, Harada N, Chiba A, Harada S, Matsuno K, Makino F, Ito J, Ohta S, Ono J, Atsuta R, Izuhara K, Takahashi K, Miyake S: Circulating activated innate lymphoid cells and mucosal-associated invariant $\mathrm{T}$ cells are associated with airflow limitation in patients with asthma. Allergol Int, 2017; 66: 302-309.

20) Toyoki M, Hase M, Hirasawa Y, Umeyama T, Miyazaki Y, Kano R, Sugita T, Hiruma M, Kodama Y, Ikeda S: A Giant Dermatophyte Abscess Caused by Trichophyton rubrum in an Immunocompromised Patient. Med Mycol J, 2017; 58: E63-E66.

21) Onodera K, Sugiura H, Yamada M, Koarai A, 
Fujino N, Yanagisawa S, Tanaka R, Numakura T, Togo S, Sato K, Kyogoku Y, Hashimoto Y, Okazaki T, Tamada T, Kobayashi S, Yanai M, Miura M, Hoshikawa Y, Okada Y, Suzuki S, Ichinose M: Decrease in an antiageing factor, growth differentiation factor 11 , in chronic obstructive pulmonary disease. Thorax, 2017; 72: 893-904.

22) Gupta N, Finlay GA, Kotloff RM, Strange C, Wilson KC, Young LR, Taveira-DaSilva AM, Johnson SR, Cottin V, Sahn SA, Ryu JH, Seyama K, Inoue Y, Downey GP, Han MK, Colby TV, Wikenheiser-Brokamp KA, Meyer CA, Smith K, Moss J, McCormack FX; ATS Assembly on Clinical Problems: Lymphangioleiomyomatosis Diagnosis and Management: High-Resolution Chest Computed Tomography, Transbronchial Lung Biopsy, and Pleural Disease Management. An Official American Thoracic Society/Japanese Respiratory Society Clinical Practice Guideline. Am J Respir Crit Care Med, 2017; 196: 1337-1348.

23) Saito M, Fujiwara $Y$, Asao $T$, Honda $T$, Shimada Y, Kanai Y, Tsuta K, Kono K, Watanabe S, Ohe Y, Kohno T: The genomic and epigenomic landscape in thymic carcinoma. Carcinogenesis, 2017; 38: 1084-1091.

*24) Konagai A, Yoshimura K, Hazama S, Yamamoto N, Aoki K, Ueno T, Fujioka M, Iijima H, Kato M, Uchida M, Wada T, Inoue M, Asao T, Fuse M, Wada S, Kuramasu A, Kamei R, Takeda S, Yamamoto S, Yoshino S, Oka M, Nagano H: Correlation between NKG2DL expression and antitumor effect of proteinbound polysaccharide- $\mathrm{K}$ in tumor-bearing mouse models. Anticancer Res, 2017; 37: 4093-4101.

25) Nakamichi S, Horinouchi H, Asao T, Goto Y, Kanda S, Fujiwara Y, Nokihara H, Yamamoto $\mathrm{N}$, Ito Y, Watanabe S, Ohe Y: Comparison of radiotherapy and chemoradiotherapy for locoregional recurrence of non-small-cell lung cancer developing after surgery. Clin Lung Cancer, 2017; 18: e441-e448.

26) Okuma HS, Horinouchi H, Kitahara S, Asao T, Sunami K, Goto Y, Kanda S, Fujiwara Y, Nokihara H, Yamamoto N, Ohe Y: Comparison of amrubicin and weekly cisplatin/ etoposide/irinotecan in patients with relapsed small-cell lung cancer. Clin Lung Cancer, 2017; 18: 234-240.

27) Asao T, Fujiwara $Y$, Itahashi K, Kitahara S, Goto Y, Horinouchi H, Kanda S, Nokihara H, Yamamoto N, Ohe Y: Sequential use of anaplastic lymphoma kinase inhibitors in Japanese patients with ALK-rearranged nonsmall-cell lung cancer: A retrospective analysis. Clin Lung Cancer, 2017; 18: e251-e258.

28) Takagi H, Nagaoka T, Ando K, Tsutsumi T, Ichikawa M, Koyama R, Shimada N, Tobin K, Takahashi K: Efficacy of Antibiotic Prophylaxis after Endobronchial Ultrasound-guided Transbronchial Needle Aspiration: A Preliminary Prospective Study. J Pulm Respir Med, 2017; 7: 416.

29) Hida $T$, Nokihara H, Kondo M, Kim YH, Azuma K, Seto T, Takiguchi Y, Nishio M, Yoshioka H, Imamura F, Hotta K, Watanabe S, Goto K, Satouchi M, Kozuki T, Shukuya T, Nakagawa K, Mitsudomi T, Yamamoto N, Asakawa T, Asabe R, Tanaka T, Tamura T: Alectinib versus crizotinib in patients with ALK-positive non-small-cell lung cancer (J-ALEX): an open-label, randomised phase 3 trial. Lancet, 2017; 390: 29-39.

*30) Ebana H, Hayashi T, Mitani K, Kobayashi E, Kumasaka T, Mizobuchi T, Kurihara M, Takahashi F, Takahashi K, Seyama K: Oxidized Regenerated Cellulose Induces Pleural Thickening in Patients with Pneumothorax, Possible Involvement of Mesothelial-Mesenchymal Transition. Surg Today, 2017; 48: 462-472.

31) Ai T, Yuri M, Tabe Y, Kakimoto A, Morishita S, Tsuchiya K, Takamochi K, Kodama Y, Takahashi F, Shigeki M, Horii T, Suzuki K, Takahashi K, Miida T, Ohsaka A: A comparison of the analytical performance between cobas EGFR assay and PCR-Clamp methods in the detection of EGFR mutations in Japanese non-small cell lung cancer patients. Clin Lab, 2017; 63: 1021-1026.

32) Nurwidya F, Takahashi F, Kato M, Baskoro H, Hidayat M, Wirawan A, Takahashi K: CD44 silencing decreases the expression of stem cell-related factors induced by transforming growth factor $\beta 1$ and tumor necrosis factor $\alpha$ in lung cancer. Bosn J Basic Med Sci, 2017; 17: 228-234. 
33) Takamochi K, Takahashi F, Suehara Y, Kitano S, Sato E, Kohsaka S, Hayashi T, Mano H, Suzuki K: DNA mismatch repair deficiency in surgically resected lung adenocarcinoma: Microsatellite instability analysis using the Promega panel Lung Cancer. Lung Cancer, 2017; 110: 26-31.

34) Sandhu Y, Ando K, Takekawa H, Takagi H, Hirama M, Kido K, Takahashi K: Safety of Bronchoscopy for Patients with Hemodialysis. Respir Investig, 2017; 55: 173-175.

$\langle$ Books $\rangle$

1) Sato T, Seyama K: Pathogenesis of COPD 3: Oxidative Stress - Is There a Possibility of Developing New Drugs from the Standpoint of This Pathogenetic Mechanism? In: Nakamura H, Aoshiba K, eds. Chronic Obstructive Pulmonary Disease: A Systemic Inflammatory Disease. Singapore; Springer, 2017; 7393.

2) Sakamoto N, Takiguchi S, Komatsu K, Okuyama T, Nakaguchi T, Kubota Y, Ito Y, Sugano K, Wada M, Akechi T: Supportive care needs and psychological distress and/or quality of life in ambulatory advanced colorectal cancer patients receiving chemotherapy: a cross-sectional study. Jpn J Clin Oncol, 2017; 47: 1157-1161.

\section{Department of Metabolism \& Endocrinology}

〈Original Articles〉

1) Yokomichi H, Nagai A, Hirata M, Kiyohara $Y$, Muto K, Ninomiya T, Matsuda K, Kamatani Y, Tamakoshi A, Kubo M, Nakamura Y, BioBank Japan Cooperative Hospital Group, Yamagata Z: Survival of macrovascular disease, chronic kidney disease, chronic respiratory disease, cancer and smoking in patients with type 2 diabetes: BioBank Japan cohort. J Epidemiol, 2017; 27: S98-S106.

2) Yamamoto Y, Miyatsuka T, Sasaki S, Miyashita K, Kubo F, Shimo N, Takebe S, Watada H, Kaneto H, Matsuoka T, Shimomura I: Preserving expression of $\mathrm{Pdx} 1$ improves $\beta$ cell failure in diabetic mice. Biochem Biophys Res Commun, 2017; 483: 418-424.

3) Watada H, Su Q, Li P, Iwamoto N, Qian L, Yang W: Comparison of insulin lispro mix 25 with insulin lispro mix 50 as an insulin starter in Asian patients with type 2 diabetes: a phase 4, open-label, randomized trial (CLASSIFY study). Diabetes Metab Res Rev, 2017; 33: e2816.

4) Watada H, Imori M, Li P, Iwamoto N: Insulin lispro 25/75 and insulin lispro 50/50 as starter insulin in Japanese patients with type 2 diabetes: subanalysis of the CLASSIFY randomized trial. Endocr J, 2017; 64: 705717.

5) Uchida T, Nishimoto K, Fukumura $\mathrm{Y}$, Asahina M, Goto H, Kawano Y, Shimizu F, Tsujimura A, Seki T, Mukai K, Kabe Y, Suematsu M, Sanchez GC, Yao T, Horie S, Watada H: Disorganized Steroidogenesis in Adrenocortical Carcinoma, a Case Study. Endocr Pathol, 2017; 28: 27-35.

6) Takahashi A, Ohira T, Hosoya M, Yasumura S, Nagai M, Ohira H, Hashimoto S, Satoh H, Sakai A, Ohtsuru A, Kawasaki Y, Suzuki H, Kobashi G, Ozasa K, Yamashita S, Kamiya K, Abe M; Fukushima Health Management Survey G: Effect of evacuation on liver function after the Fukushima Daiichi Nuclear Power Plant accident: The Fukushima Health Management Survey. J Epidemiol, 2017; 27: 180185.

7) Suzuki L, Kanazawa A, Uzawa H, Osonoi Y, Masuyama A, Azuma K, Takeno K, Takayanagi N, Sato J, Someya Y, Komiya K, Goto H, Mita T, Ikeda F, Ogihara T, Shimizu T, Ohmura C, Saito M, Osonoi T, Watada H: Safety and efficacy of metformin up-titration in Japanese patients with type 2 diabetes mellitus treated with vildagliptin and lowdose metformin. Expert Opin Pharmacother, 2017; 18: 1921-1928.

8) Suzuki L, Hirayama S, Fukui M, Sasaki M, Hiroi S, Ayaori M, Terai S, Tozuka M, Watada $\mathrm{H}$, Miida T: Lipoprotein-X in cholestatic patients causes xanthomas and promotes foam cell formation in human macrophages. J Clin Lipidol, 2017; 11: 110-118.

9) Sugaya Y, Satoh H: Liver-specific G0/G1 switch gene 2 ( $\mathrm{G} 0 \mathrm{~s} 2)$ expression promotes hepatic insulin resistance by exacerbating hepatic steatosis in male Wistar rats. J Diabetes, 2017; 9: 754-763.

10) Shigiyama F, Kumashiro N, Furukawa Y, 
Funayama T, Takeno K, Wakui N, Ikehara T, Nagai H, Taka H, Fujimura T, Uchino H, Tamura Y, Watada H, Nemoto T, Shiraga N, Sumino Y, Hirose T: Characteristics of hepatic insulin-sensitive nonalcoholic fatty liver disease. Hepatol Commun, 2017; 1: 634-647.

11) Satoh H, Ohira T, Moriya C, Inoue I, Kuribayashi S, Seino H, Hirai H, Hiyoshi T, Watada H; L-CGM Study Group: Effects of linagliptin vs. voglibose on daily glucose excursions during continuous glucose monitoring of Japanese type 2 diabetes patients (L-CGM): A randomized, open-label, twoarm, parallel comparative trial. Diabetes Metab, 2017; 43: 550-553.

12) Sato J, Uchida T, Komiya K, Goto H, Takeno K, Suzuki R, Honda A, Himuro M, Watada H: Comparison of the therapeutic effects of prednisolone and nonsteroidal anti-inflammatory drugs in patients with subacute thyroiditis. Endocrine, 2017; 55: 209-214.

13) Sato J, Kanazawa A, Makita S, Hatae C, Komiya K, Shimizu T, Ikeda F, Tamura Y, Ogihara T, Mita T, Goto H, Uchida T, Miyatsuka T, Takeno K, Shimada S, Ohmura C, Watanabe T, Kobayashi K, Miura Y, Iwaoka M, Hirashima N, Fujitani Y, Watada H: A randomized controlled trial of $130 \mathrm{~g} /$ day lowcarbohydrate diet in type 2 diabetes with poor glycemic control. Clin Nutr, 2017; 36: 992-1000.

14) Sato J, Kanazawa A, Hatae C, Makita S, Komiya K, Shimizu T, Ikeda F, Tamura Y, Ogihara T, Mita T, Goto H, Uchida T, Miyatsuka T, Ohmura C, Watanabe T, Kobayashi K, Miura Y, Iwaoka M, Hirashima $\mathrm{N}$, Watada H: One year follow-up after a randomized controlled trial of a $130 \mathrm{~g} /$ day low-carbohydrate diet in patients with type 2 diabetes mellitus and poor glycemic control. PLoS One, 2017; 12: e0188892.

15) Sato J, Kanazawa A, Azuma K, Ikeda F, Goto H, Komiya K, Kanno R, Tamura Y, Asahara T, Takahashi T, Nomoto K, Yamashiro Y, Watada $\mathrm{H}$ : Probiotic reduces bacterial translocation in type 2 diabetes mellitus: A randomised controlled study. Sci Rep, 2017; 7: 12115.

16) Sakai A, Nakano H, Ohira T, Hosoya M, Yasumura S, Ohtsuru A, Satoh H, Kawasaki
Y, Suzuki H, Takahashi A, Sugiura Y, Shishido H, Hayashi Y, Takahashi H, Kobashi G, Ozasa K, Hashimoto S, Ohto H, Abe M; Fukushima Health Management Survey Group: Persistent prevalence of polycythemia among evacuees 4 years after the Great East Japan Earthquake: A follow-up study. Prev Med Rep, 2017; 5: 251-256.

17) Saito D, Kanazawa A, Shigihara N, Sato F, Uchida T, Sato J, Goto H, Miyatsuka T, Ikeda F, Ogihara T, Ohmura C, Watada H: Efficacy and Safety of Vildagliptin as an Add-On Therapy in Inadequately Controlled Type 2 Diabetes Patients Treated with Basal Insulin. J Clin Med Res, 2017; 9: 193-199.

18) Sai E, Shimada K, Yokoyama T, Hiki M: Sato S, Hamasaki N, Maruyama M, Morimoto R, Miyazaki T, Fujimoto S, Tamura Y, Aoki S, Watada H, Kawamori R, Daida H: Myocardial triglyceride content in patients with left ventricular hypertrophy: comparison between hypertensive heart disease and hypertrophic cardiomyopathy. Heart Vessels, 2017; 32: 166-174.

19) Osada T, Suzuki R, Ogawa A, Tanaka M, Hori M, Aoki S, Tamura Y, Watada H, Kawamori R: Functional subdivisions of the hypothalamus using areal parcellation and their signal changes related to glucose metabolism. Neuroimage, 2017; 162: 1-12.

20) Onose H, Uchida T, Sato J, Ishii S, Yamada E, Yamada T, Watada H: Monocyte and Basophil Counts as Predictors of Neutrophil Count Recovery in Patients with Thiamazoleinduced Agranulocytosis. Exp Clin Endocrinol Diabetes, 2017; 125: 49-52.

21) Ohkuma T, Tomiyama H, Ninomiya $T$, Kario K, Hoshide S, Kita Y, Inoguchi T, Maeda Y, Kohara K, Tabara Y, Nakamura M, Ohkubo T, Watada H, Munakata M, Ohishi M, Ito N, Nakamura M, Shoji T, Vlachopoulos C, Yamashina A: Proposed Cutoff Value of Brachial-Ankle Pulse Wave Velocity for the Management of Hypertension. Circ J, 2017; 81: 1540-1542.

22) Ohkuma T, Ninomiya T, Tomiyama H, Kario K, Hoshide S, Kita Y, Inoguchi T, Maeda Y, Kohara K, Tabara Y, Nakamura M, Ohkubo T, Watada H, Munakata M, Ohishi M, Ito N, 
Nakamura M, Shoji T, Vlachopoulos C, Yamashina A; Collaborative Group for JBavel (Japan Brachial-Ankle Pulse Wave Velocity Individual Participant Data MetaAnalysis of Prospective Studies): BrachialAnkle Pulse Wave Velocity and the Risk Prediction of Cardiovascular Disease: An Individual Participant Data Meta-Analysis. Hypertension, 2017; 69: 1045-1052.

23) Ogihara T, Mita T, Osonoi $Y$, Osonoi T, Saito M, Tamasawa A, Nakayama S, Someya Y, Ishida H, Gosho M, Kanazawa A, Watada H: Relationships between lifestyle patterns and cardio-renal-metabolic parameters in patients with type 2 diabetes mellitus: A crosssectional study. PLoS One, 2017; 12: $\mathrm{e} 0173540$.

24) Odawara M, Kawamori R, Tajima N, Iwamoto Y, Kageyama S, Yodo Y, Ueki F, Hotta N: Long-term treatment study of global standard dose metformin in Japanese patients with type 2 diabetes mellitus. Diabetol Int, 2017; 8: 286-295.

25) Nishioka K, Uchida T, Usui C, Tanaka R, Matsushima T, Matsumoto Y, Nakamura I, Nishioka K, Hattori N: High prevalence of anti-TSH receptor antibody in fibromyalgia syndrome. Int J Rheum Dis, 2017; 20: 685690.

26) Mita T, Katakami N, Shiraiwa T, Yoshii H, Kuribayashi N, Osonoi T, Kaneto H, Kosugi K, Umayahara Y, Gosho M, Shimomura I, Watada H: Relationship between frequency of hypoglycemic episodes and changes in carotid atherosclerosis in insulin-treated patients with type 2 diabetes mellitus. Sci Rep, 2017; 7: 39965.

27) Mita T, Katakami N, Shiraiwa T, Yoshii H, Gosho M, Shimomura I, Watada H, Sitagliptin Preventive Study of Intima-media Thickness Evaluation T: Changes in carotid intimamedia thickening in patients with type 2 diabetes mellitus: Subanalysis of the Sitagliptin Preventive Study of Intima-Media Thickness Evaluation. J Diabetes Investig, 2017; 8: 254-255.

28) Mita T, Katakami N, Shiraiwa T, Yoshii H, Gosho M, Shimomura I, Watada H: DoseDependent Effect of Sitagliptin on Carotid
Atherosclerosis in Patients with Type 2 Diabetes Mellitus Receiving Insulin Treatment: A Post Hoc Analysis. Diabetes Ther, 2017; 8: 1135-1146.

29) Mita T, Katakami N, Shiraiwa T, Yoshii H, Gosho M, Shimomura I, Watada H: The Effect of Sitagliptin on the Regression of Carotid Intima-Media Thickening in Patients with Type 2 Diabetes Mellitus: A Post Hoc Analysis of the Sitagliptin Preventive Study of Intima-Media Thickness Evaluation. Int J Endocrinol, 2017; 2017: 1925305.

30) Mita T, Katakami N, Shiraiwa T, Yoshii H, Gosho M, Ishii H, Shimomura I, Watada H, Spike Trial Site Investigators: The Influence of Sitagliptin on Treatment-Related Quality of Life in Patients with Type 2 Diabetes Mellitus Receiving Insulin Treatment: A Prespecified Sub-Analysis. Diabetes Ther, 2017; 8: 693-704.

31) Kuramitsu S, Miyauchi K, Yokoi H, Suwa S, Nishizaki Y, Yokoyama T, Nojiri S, Iwabuchi M, Shirai S, Ando K, Okazaki S, Tamura H, Watada H, Daida H: Effect of sitagliptin on plaque changes in coronary artery following acute coronary syndrome in diabetic patients: The ESPECIAL-ACS study. J Cardiol, 2017; 69: 369-376.

32) Koga M, Inada S, Nakao T, Kawamori R, Kasayama S: The Glycated Albumin (GA) to HbA1c Ratio Reflects Shorter-Term Glycemic Control than GA: Analysis of Patients with Fulminant Type 1 Diabetes. J Clin Lab Anal, 2017; 31: e22023.

33) Katakami N, Mita T, Yoshii H, Shiraiwa T, Yasuda T, Okada Y, Umayahara Y, Kaneto H, Osonoi T, Yamamoto T, Kuribayashi N, Maeda K, Yokoyama H, Kosugi K, Ohtoshi K, Hayashi I, Sumitani S, Tsugawa M, Ohashi M, Taki H, Nakamura T, Kawashima S, Sato Y, Watada H, Shimomura I; UTOPIA study investigators: Rationale, Design, and Baseline Characteristics of the Utopia Trial for Preventing Diabetic Atherosclerosis Using an SGLT2 Inhibitor: A Prospective, Randomized, Open-Label, Parallel-Group Comparative Study. Diabetes Ther, 2017; 8: 999-1013.

34) Kaga H, Tamura Y, Takeno K, Kakehi S, Funayama T, Furukawa Y, 
Nishitani-Yokoyama M, Shimada K, Daida H, Aoki S, Giacca A, Kanazawa A, Kawamori R, Watada H: Correlates of insulin clearance in apparently healthy non-obese Japanese men. Sci Rep, 2017; 7: 1462.

35) Ji L, Bonnet F, Charbonnel B, Gomes M: B, Kosiborod M, Khunti K, Nicolucci A, Pocock S, Rathmann W, Shestakova MV, Shimomura I, Watada H, Fenici P, Hammar N, Hashigami K, Macaraeg G, Surmont F, Medina J: Towards an improved global understanding of treatment and outcomes in people with type 2 diabetes: Rationale and methods of the DISCOVER observational study program. J Diabetes Complications, 2017; 31: 1188-1196.

36) Ishii $H$, Niiya $T$, Ono $Y$, Inaba $N$, Jinnouchi $H$, Watada H: Improvement of quality of life through glycemic control by liraglutide, a GLP-1 analog, in insulin-naive patients with type 2 diabetes mellitus: the PAGE1 study. Diabetol Metab Syndr, 2017; 9: 3.

37) Honda A, Uchida T, Komiya K, Goto H, Takeno K, Sato J, Suzuki R, Himuro M, Watada H: RELATIONSHIP BETWEEN THE EFFECTIVENESS OF INORGANIC IODINE AND THE SEVERITY OF GRAVES' THYROTOXICOSIS: A RETROSPECTIVE STUDY. Endocr Pract, 2017; 23: 1408-1413.

38) Hashimoto S, Nagai M, Fukuma S, Ohira T, Hosoya M, Yasumura S, Satoh H, Suzuki H, Sakai A, Ohtsuru A, Kawasaki Y, Takahashi A, Ozasa K, Kobashi G, Kamiya K, Yamashita S, Fukuhara S, Ohto H; Fukushima Health Management Survey G: Influence of Postdisaster Evacuation on Incidence of Metabolic Syndrome. J Atheroscler Thromb, 2017; 24: $327-337$.

39) Hamamura M, Mita T, Osonoi Y, Osonoi T, Saito M, Tamasawa A, Nakayama S, Someya Y, Ishida H, Gosho M, Kanazawa A, Watada H: Relationships Among Conventional Cardiovascular Risk Factors and Lifestyle Habits with Arterial Stiffness in Type 2 Diabetic Patients. J Clin Med Res, 2017; 9: 297-302.

40) Furukawa Y, Tamura Y, Takeno K, Funayama T, Kaga H, Suzuki R, Watanabe T,
Kakehi S, Kanazawa A, Kawamori R, Watada $\mathrm{H}$ : Impaired peripheral insulin sensitivity in non-obese Japanese patients with type 2 diabetes mellitus and fatty liver. J Diabetes Investig, Epub 2017 Aug 24.

41) Funayama T, Tamura $Y$, Takeno K, Kawaguchi M, Kakehi S, Watanabe T, Furukawa Y, Kaga H, Yamamoto R, Kanazawa A, Fujitani Y, Kawamori R, Watada H: Effects of alcohol abstinence on glucose metabolism in Japanese men with elevated fasting glucose: A pilot study. Sci Rep, 2017; 7: 40277.

42) Fukunaka A, Fukada T, Bhin J, Suzuki L, Tsuzuki T, Takamine Y, Bin BH, Yoshihara T, Ichinoseki-Sekine N, Naito H, Miyatsuka $\mathrm{T}$, Takamiya S, Sasaki T, Inagaki T, Kitamura T, Kajimura S, Watada H, Fujitani Y: Zinc transporter ZIP13 suppresses beige adipocyte biogenesis and energy expenditure by regulating $\mathrm{C} / \mathrm{EBP}-\beta$ expression. Plos Genetics, 2017; 13: e1006950.

43) Eshima H, Tamura Y, Kakehi S, Kurebayashi N, Murayama T, Nakamura K, Kakigi R, Okada T, Sakurai T, Kawamori R, Watada H: Long-term, but not short-term high-fat diet induces fiber composition changes and impaired contractile force in mouse fast-twitch skeletal muscle. Physiol Rep, 2017; 5: e13250.

44) Chen W, Qian L, Watada H, Li P, Iwamoto N, Imori M, Yang W: Impact of diet on the efficacy of insulin lispro mix 25 and insulin lispro mix 50 as starter insulin in East Asian patients with type 2 diabetes: Subgroup analysis of the Comparison Between Low Mixed Insulin and Mid Mixed Insulin as Starter Insulin For Patients with Type 2 Diabetes Mellitus (CLASSIFY Study) randomized trial. J Diabetes Investig, 2017; 8: 75-83.

〈Reviews〉

1) Watada H, Tamura Y: Impaired insulin clearance as a cause rather than a consequence of insulin resistance. J Diabetes Investig, 2017; 8: 723-725.

2) Sato J, Kanazawa A, Watada H: Type 2 Diabetes and Bacteremia. Ann Nutr Metab, 2017; 71 Suppl 1: 17-22. 